\title{
The Contribution of Outward Foreign Direct Investment, Human Well-Being, and Technology toward a Sustainable Environment
}

\author{
Qianxiao Zhang ${ }^{1}{ }^{(}$, Syed Asif Ali Naqvi ${ }^{2}{ }^{\circledR}$ and Syed Ale Raza Shah ${ }^{1, *}$ \\ 1 School of Economics \& Finance, Xi'an Jiaotong University, Xi'an 710061, China; zhqxiao@mail.xjtu.edu.cn \\ 2 Department of Economics, Government College University, Faisalabad 38040, Pakistan; \\ syedasif_1@yahoo.com \\ * Correspondence: shahsyedaleraza@stu.xjtu.edu.cn; Tel.: +92-3145141218
}

Citation: Zhang, Q.; Naqvi, S.A.A.; Shah, S.A.R. The Contribution of Outward Foreign Direct Investment, Human Well-Being, and Technology toward a Sustainable Environment. Sustainability 2021, 13, 11430. https:// doi.org/10.3390/su132011430

Academic Editor: Bruce Morley

Received: 12 August 2021

Accepted: 12 October 2021

Published: 16 October 2021

Publisher's Note: MDPI stays neutral with regard to jurisdictional claims in published maps and institutional affiliations.

Copyright: (c) 2021 by the authors. Licensee MDPI, Basel, Switzerland. This article is an open access article distributed under the terms and conditions of the Creative Commons Attribution (CC BY) license (https:/ / creativecommons.org/licenses/by/ $4.0 /)$.

\begin{abstract}
This study evaluates the impact of outward foreign direct investment (OFDI), human well-being, and other macro indicators of the public sector on carbon footprint. Empirical analysis has been carried out for newly industrialized economies that span the period 1990-2017. We used augmented mean group and bootstrap panel causality techniques to cogitate the cross-sectional dependence and country-specific heterogeneity. Based on cross-country analysis, study results show that growing OFDI reduces carbon footprint efficiently in Mexico and Turkey, human wellbeing decreases emissions in the Philippines, and urbanization reduces emissions in China. Further, technology reduces emissions in Malaysia and Turkey, trade openness reduces emissions in China and Malaysia, and natural resource rents reduce emissions in Indonesia and Mexico. In the case of panel analysis, the moderating role of OFDI with human well-being is contributing toward a sustainable environment. Moreover, the moderation of OFDI and urbanization has an insignificant impact on CFP. Findings depict that interaction terms of OFDI with technology and trade openness have a positive association with the environment quality. Finally, OFDI and natural resources have positive moderation on CFP. This study contributes to the existing literature by suggesting policy implications for a sustainable environment.
\end{abstract}

Keywords: OFDI; sustainable environment; carbon emission; technology; natural resources; HDI

\section{Introduction}

Since the last two decades, newly industrialized countries (NIC) have observed rapid economic development and switched from agricultural to industrial and, finally, servicedriven economies, accompanied by a growth in OFDI. However, this development has been achieved at the cost of the environment. Nowadays, the economic developmentenvironmental degradation (ED) nexus has become a hot issue for development and environmental economists. In recent years, studies have explored this critical association through different econometric methods and panels of countries and found economic development a significant contributor to carbon emission. There are diverse viewpoints regarding the aforementioned nexus. Many studies endorse the leading work of Grossman and Krueger about EKC hypothesis [1], who claimed that in the early stage of economic growth, environment pollution rises, but afterward, environment pollution diminishes as income rises and vice versa [2-6].

According to another school of thought, energy use and other input indicators are the key reasons for worldwide environmental pollution [7-9]. Further, several studies weighted the causal association between development and ED [10-13] and extensively debated the reasons behind this interesting link. However, in recent years, the role of OFDI in the development-emission nexus is getting vast attention, and little work has been performed in this domain. On the other hand, capital drainage has played a vital 
role in economic development, but it has terrible effects on the environment. Indeed, the influences of OFDI on environmental pollution are byzantine.

On one side, OFDI efficiently promotes green technology innovation competency of home-based initiatives and advances energy efficacy through resource spillover impacts by decreasing environmental pollution. Instead, transferring the home nation's high pollution manufacturing to a host nation through OFDI can also diminish the ED in the home nation. OFDI may also encourage economic development through reserve technology spillovers, and this development may increase ED. The primary motive of OFDI is to enhance market share, which will raise the manufacturing of domestic intermediate products, thus cumulate the ED of a home nation [14].

Economic development and ED have diverse impacts on OFDI. One of these is about the direct influence of OFDI on economic growth. Agnihotri and Arora [15] inspected the implication of OFDI behavior and debated that it is a supportive instrument for economic growth in India's case. For instance, Chen [16] suggested a noteworthy positive link between economic growth and OFDI. In addition, various researchers investigated the relation between OFDI and economic growth [17-19]. Another group of studies examined the indirect impact of OFDI on ED, such as Hao et al. [20], who concluded that OFDI negatively influences the environment. Likewise, in this direction, various studies estimated the exciting relationship between OFDI and environment quality by using different panels and time-series analyses [21-25].

Overall, the above literature in this stream claimed inconsistent findings regarding the effects of OFDI, economic development, and economic indicators on environmental quality and imitated a lack of agreement. This study is a breakthrough to cognize the vague linkage of OFDI and economic development with environmental quality by using interaction terms as additional variables. This study measures the impact of OFDI on economic development (HDI) and carbon footprints (CFP) by incorporating natural resource rents (NR), technology, urbanization (URB), and trade openness (TO) in a single multivariate framework. This article shows a new contrivance for reconnoitering the exciting role of OFDI for economic development-emission nexus in the NIC economies.

This study has proposed a hypothesis that OFDI can perform well to raise the environment quality. Hence, this factor is considered a driving force behind the success story of technology transfer, more use of resources, and overall development of the region. Researchers across the globe have tried to investigate the origin of climate change and ways to resolve this problem, but they could not reach a single opinion. Sustainability theory reveals that this dilemma is closely related to the resources of economies. This article has undertaken the main and moderate effects of environmental determinants and contributes to the prevailing literature in the following notable aspects.

(1) This study has included an innovative series of environmental determinants: OFDI, human HDI, technology, urbanization, natural resources, and TO. This paper focuses on the dominant role of OFDI with human well-being and technology in NIC economies, which has been neglected previously. Other selected determinants of ED also have a vital role in the environmental situation and are given equal weightage in the model.

(2) This work estimates each variable's main effect against CFP and answers the critical question of whether OFDI connection with ED is green or harmful to the environment (keeping all variables). If this determinant is detrimental to environmental quality, how can NIC economies attain the sustainable development goals (SDGs) by having such behavior? This study discusses the possible ways to solve this situation.

(3) This study introduces the interaction term of OFDI with each environment indicator. Through the moderate effect (interaction term), the study measures the spillover effect of OFDI toward each variable and suggests ways to promote human well-being, TO, technology, and NR for a sustainable environment.

(4) Along with the panel analysis, the study estimates the cross-country analysis to measure the response of every indicator to each country's environment. Furthermore, on behalf of outcomes, this study suggests policies for each economy in short. 
(5) We used both the coefficient estimator and the causality methodology to consider cross-sectional and country-specific heterogeneities. In economic and ED literature, most of the traditional econometric techniques have been applied, such as ordinary least square (OLS), panel mean group (PMG), and generalized method of moments (GMM). Nevertheless, these estimators suppose the effect of every country under the common shocks, which is common across them. Further, these techniques consider the stationarity of the underlying series, which may cause seriously biased quantifications if the data follow the unit root test. Moreover, the said methods assume the independence of error. For the macroeconomic panel, all of these suppositions seem unrealistic [26]. Bond and Eberhardt [27] and Dong et al. [28] developed a more general estimator for the large heterogeneous panel with the multifactor error structure, called augmented mean group (AMG), which is applicable in both heterogeneity and cross-sectional dependence (CD) issues and our study has used this method. AMG has already been used by various studies references [29-34]. The selection of this technique is based on the given background. Bootstrap panel causality models have also been employed to handle integrated analytical work, unlike most of the existing statistical work that used cointegration and multivariate Granger's causality frameworks.

The rest of the paper is divided as follows: The literature review is given in Section 2. Section 3 consists of data and methods. Section 4 consists of results and discussion. Lastly, Section 5 fetches the conclusion and policy recommendations.

\section{Literature Review}

Climatic variations and related dangers to human welfare are crucial points and policy priorities for the inclusive agenda. So, sustainable development is centered on the two key pillars, i.e., economic and environmental sustainability, that has attained substantial significance for humanity [35]. This section has been divided into three sub-sections: (1) nexus between economic indicators and development, (2) nexus between OFDI and ED, and (3) the influential factors of FDI.

\subsection{Relationship between OFDI, NR, URB, Technology, TO, and Economic Development}

The first subsection discusses the studies that estimated the long-run association between different economic indicators. For instance, Liu et al. [36] investigated the determinants of Chinese OFDI in the case of 93 economies (49 from OBOR and 44 outside the OBOR). The study employed the sys-GMM and FGLS techniques and found that the technology and TO enhanced OFDI. Kim and Lin [37] analyzed the link between NR and growth in 46 developing economies. The CCEMG and AMG analyses summarized the negative impact of NR on GDP and supported the natural curse hypothesis. Bilgili et al. [38] examined urbanization and technology (EI) in 10 Asian economies from 1990 through 2014. Using the AMG technique, they found the positive contribution of urbanization to technology.

Later on, Wang et al. [39] investigated the association of income, urbanization, industrialization, and carbon emissions to decoupling in China and Indian economies by covering 1980-2014. They employed Johnson cointegration, and results showed that emission significantly contributes to decoupling for both selected economies. Similarly, the study of top-resource abundant economies by Ben-Salha et al. [40] linked NR and economic growth from 1970 through 2013. The outcomes of the PMG technique represented the positive relationship between GDP and NR. Further, they also found a two-way causal association between NR and GDP.

Soon after, research work related to OFDI, human capital, and economic growth by Mohanty and Sethi [41] for BRICS economies. Using the cointegration method over 1985-2017, they estimated a positive influence of OFDI on economic growth. In addition, they quantified the positive impact of OFDI on economic growth. A bidirectional causality between human capital and OFDI was seen. Likewise, Zallé [42] examined the nexus of NR, institutional quality, human capital, and economic growth in the case of 29 African countries during 2000-2015. They measured that human capital can perform well in NR 
blessing by controlling the corruption. Ramzan et al. [43] investigated the association of TO and total factor productivity with economic growth in 82 economies over 1980-2014. The outcomes of the GMM technique showed the non-linear pattern between trade and economic growth by considering the TFP variable. They elaborated that the minimum threshold level of TFP and TO has a positive response to boost economic growth.

In recent years, Saleh et al. [44] examined the association of economic growth, NR, human resources, society's culture, and regulations. The study found a positive response of all indicators toward economic growth, while NR showed a massive contribution to economic growth. Canh et al. [45] examined the association of economic complexity and NR for different income groups by using economic growth, FDI inflows, capital investment, and government consumption as control variables. The outcomes of this study revealed that economic complexity has a muted impact on NR in lower- and higher-income economies. Bingquan et al. [46] studied the long-run link between urbanization and growth in China's case from 2007 to 2016, and concluding remarks showed mixed findings for urbanization and GDP. Likewise, Kong et al. [47] discovered the relation between GDP and TO for China during 1994-2018 and found an N-shaped relationship between TO and economic growth.

\subsection{Relationship between OFDI, NR, URB, Technology, TO, and ED}

This subsection overviews past studies in the domain of environmental quality. For instance, a case study related to China's OFDI estimated the effect of China's OFDI on environmental quality by considering 34 host economies [48]. They concluded that OFDI could perform well in the decline of emissions by suitable industry location. In 2018, Yi et al. examined the impact of urbanization and OFDI on carbon emissions in China [49]. By using the Markov switching regression model, they found the positive contribution of OFDI in carbon emissions. Furthermore, they observed a decline in carbon emissions due to a $1 \%$ rise in emissions. An empirical investigation of [50] demonstrated the green spillover effect of OFDI on growth for the 30 provinces of China during the period 20062015 and concluded that the Chinese OFDI is spilling over to its green growth. For the case of China, Hao et al. [20] investigated the association of outwards FDI with environmental quality over 2003-2016. Their results revealed the heterogeneous impact of technical, scale, and composition effects of OFDI on environmental quality. Pan et al. [51] examined the association of Chinese OFDI with technical spillover from 2004 to 2016 by employing the spatial Durbin model. They found that the technical spillovers of OFDI help in increasing the level of total factor productivity growth. Likewise, the study of Xin and Zhang [25] estimated the impact of the threshold effect of OFDI on Chinese environmental pollution by controlling energy and urbanization. Study results found a decline in environmental pollution after the threshold level of OFDI. Furthermore, results claimed a $1 \%$ rise in urbanization and energy consumption due to elevated pollution.

Likewise, a study of China estimated the connection between urbanization and energy intensity over 1995-2014 and estimated a positive relationship between urbanization and energy intensity [52]. A study about 17 SSEA economies by Behera and Dash [53] evaluated the relationship of macroeconomic indicators such as FDI, urbanization, and energy consumption with emissions using FMOLS and DOLS techniques. Concluding remarks explained FDI and energy use as the key contributors to pollution. Ouyang and Lin [54] described the effect of urbanization on the environment quality and found urbanization and energy intensity as the main factors behind the low environmental quality. Afterward, a study associated with income groups tried to estimate the relationship between energy use, urbanization, growth, and environment [55]. Their findings explained the positive long-run association among the selected variables. Likewise, a case study related to Turkey by Cetin et al. [56] inspected the long-run link between environment, openness, and energy consumption. Ending remarks elucidated the positive link among the selected variables.

Likewise, a study related to BRI-nations by Xiao et al. [57] described countries' movement to sustainable development. Later on, an interesting comparison was seen between 
two well-known groups, BRICS and MINT [58], and the study's conclusions supported the evidence of the pollution haven hypothesis. Likewise, a study related to 18 emerging economies by Zafar et al. [59] examined the positive impact of clean energy on environmental quality compared to nonrenewable energy consumption and supported the EKC hypothesis. Many studies have investigated the nexus of NR, urbanization, energy intensity, TO, and ED with the help of different proxies for both time series and panel data. For instance, Ali et al. [60] examined this relationship for Singapore, Kurniawan and Managi [61] for Indonesia, Osathanunkul et al. [62] for Thailand, Gasimli et al. [63] for Sri-Lanka, Nathaniel [64] for Nigeria, and Kwakwa et al. [65] for Ghana. Likewise, in the case of panel data, Saidi and Mbarek [66] studied the same association for selected 19 emerging economies, Ahmed et al. [67] for South Asia, Zhang et al. [68] for NIC, Bello et al. [69] for emerging nations, Destek et al. [70] for EU countries, Lv and Xu [71] for middle-income economies, Bekun et al. [72] for 16 EU economies, and Ulucak and Khan [73] for the case of BRICS economies.

\subsection{The Influential Factors of Foreign Direct Investment (FDI)}

The FDI with its determinants has been extensively discussed in the literature. Therefore, different econometric techniques have been applied to explore the factors influencing the FDI. Most of the studies used macroeconomic factors that can promote FDI in emerging economies. For instance, Asongu et al. [74] investigated FDI determinants in MINT and BRICS economies over 2001-2011. This study has employed the pooled time series and a fixed effect for the empirical analysis. The results showed that TO and infrastructure development play an important role in attracting FDI in both regions. In opposition, NR and institutional quality pose an insignificant impact on FDI in both regions. Chen and Yan [75] investigated the determinants of FDI in China using the period of 1994-2004. Using the GMM, they found that international visibility significantly contributes to the FDI. Wang and Li [76] studied the emerging and mature economies related to influential factors of FDI. Study outcomes found that the trade markets and development of capital markets are the main determinants of FDI. However, the foreign direct and indirect investment was based on arbitrage activities. Later on, Asiamah et al. [77] investigated the determinants of FDI in Ghana over the period of 1990-2015. This study employed the Johnson cointegration approach to estimating the variables' long-term association. Results claimed the negative connection of inflation, exchange rate, and interest rate with FDI. At the same time, a positive association was observed among GDP, electricity production, and telephone usage toward the FDI.

Similarly, Mahbub and Jongwanich [78] investigated FDI determinants in the power sector for Bangladesh's economy. This study used field survey data collected during the year 2015-2016. Overall, they concluded that tax exemption, land acquisition, contract, and regulatory aspects were the main determinants of FDI. For 21 economies, Canh et al. [79] examined the determinants of FDI from 2000 to 2013. They established the negative association of GDP economic policy uncertainty with FDI.

Furthermore, the study claimed that the rise in global economic uncertainty significantly contributes to the FDI. Likewise, a study of Nigeria by Adebayo and Gambiyo [80] tried to estimate the influential factors of FDI during 1981-2017. By employing the ordinary least square (OLS), the study found openness as the boost factor for FDI. On the other hand, the exchange rate showed a positive but insignificant association with the dependent variable. An interesting case study by Appiah-Kubi et al. [81] related to Sub-Saharan Africa explored the country-level governance that can influence foreign investors' predominancy. They used an innovative series of econometric techniques, namely, OLS and feasible generalized least square, to estimate the empirical results. The outcomes revealed the positive association between government effectiveness and the predominance of foreign ownership.

Moreover, they found sound political stability and efficient regulations concerning foreign owner ship predominance. Additionally, Azam and Haseeb [82] estimated the determinants of FDI in BRICS economies over the period of 1990-2018. They employed the 
first- and second-generation econometric techniques to assess the robust outcomes. The outcome showed that the energy sector, market size, trade, and tourism have a significant role in FDI. Moreover, they found that the inflation rate deteriorates the FDI.

Similarly, Appiah-Kubi et al. [83] inspected the long-term association of tax incentives and FDI for 40 African economies between 2000 and 2018. Obtained outcomes by the random effect model showed that the tax concession has an insignificant impact on FDI. Finally, they suggested that the government could not achieve main goals such as poverty reduction, sustainable development, and women empowerment without tax policy.

Despite the above-stated extensive studies, the question still leftovers about the influence of economic development and OFDI on the environment. Past literature often considered HDI and OFDI and neglected other economic variables to determine the influential impact of the interaction. This study used the composite nature of indicators to show the amplified effects on ED across the NIC economies having diverse economic structures and environmental regulations. The confirmation on behalf of the HDI and OFDI with other core variables related to the environment would help devise climate policies. The light of the overhead inspirations drives the purpose of discovering the factors of environment quality. Moreover, the variable base summary of recent studies has been provided in Appendix A, Table A1.

\section{Materials and Methods}

\subsection{Data}

NIC are the nations where economic development has crossed the benchmark of developing economies, but these have not been categorized as developed nations yet. The selection of NICs is motivated by the fact that these economies have witnessed a surge in energy consumption in the last 20 years to pursue economic growth [84]. Recently these economies are making investments for an industrial paradigm shift by replacing the export of farm products with technologically advanced products [85]. OFDI is taken as a primary explanatory variable with other variables as it may increase the efficiency of achieving the desired sustainable environment. There is a specific relation between the choices of variables. From a sustainable environment perspective for selected nations, we tend to assess OFDI's impact on ED. OFDI can help to achieve the desired environment with the support of other economic indicators such as HDI, TO, NR, urbanization, and technology.

The annual data used in this study covers the period from 1990 to 2017 for NIC; a list of countries is given in Appendix A, Table A2. The study could not consider the next years, i.e., 2018 to onward, as the latest available data for concerned economies was up to the year 2017 for variables of interest. The variables included in this study are presented in Table 1. In addition to other variables, this paper contains technology that is measured by assuming energy intensity (the ratio of energy use to real GDP), and this proxy for technology has been used by other studies also like Hao et al. [20] and Xin and Zhang [25]. The literature has widely discussed the suitability of exhausting carbon footprint as a tool for communicating life cycle environmental consequences through eco-labeling. The worldwide temperature is rising due to greenhouse gases in the atmosphere, and one of the primary culprits is economic development due to economic activities and nonrenewable energy consumption. Rugani et al. [86] presented an inclusive review of CFP studies and used it as a proxy of environmental performance indicators. Furthermore, many other studies have used this indicator as a proxy of ED [69,86-92]. 
Table 1. Description of variables.

\begin{tabular}{ccc}
\hline Variable & Unit & Source \\
\hline HDI & Human development index & Knoema online database \\
OFDI & Outward foreign direct investment (U.S. million dollar) & Knoema online database \\
NR & Natural resource rents (\% of GDP) & WDI \\
URB & Urbanization (\% of the total population) & WDI \\
TO & Trade openness (exports + imports /GDP U.S. current \$) & WDI \\
TEC & Technology (the ratio of energy use to real GDP) & WDI \\
CFP & Carbon footprint (\% of total emissions) & WDI \\
\hline
\end{tabular}

\subsection{Theoretical Background and Model Construction}

Like other countries globally, the NIC region has taken on an ambitious pledge to meet objectives before 2030 under the SDGs framework. Sustainability involves interconnections between two main dimensions, in particular socio-economic growth and environmental sustainability. Sustainable development policymakers have been attracted by the increasing evidence for linkages between socio-economic and environmental sustainability development components. The vast body of literature has covered the association between diverse environmental quality factors and economic development, and these studies have recommended numerous environmental protocols; though, these policy inferences and guidelines seem to be unsuccessful in lessening ED. An exciting relationship can be confirmed by presenting interaction variables and moderating roles, where the moderating role is the interaction of moderate variables with independent variables. We have followed a case study by Katircioğlu and Taşpinar [93] to introduce the moderating role and founded on the overhead argument, the linear association between OFDI, selected macroeconomic, and interaction variables are checked. The generalized form of the model is presented in Equation (1).

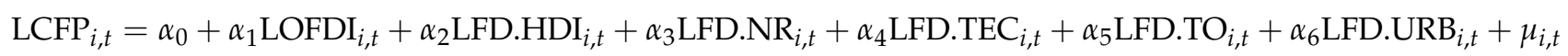

Here, $i$ shows countries, and years are denoted by $t$. The newness of this analysis lies in the interaction terms of OFDI with other selected variables. Thus, in the above-given Equation (1), LFD.HDI is denoted with the interaction variable of OFDI and HDI, LFD.NR is denoted with interaction variable of OFDI and NR, LFDTEC is denoted with OFDI and technology, LFD.TO is denoted for OFDI and TO and in the last FD.URB is indicated for the interaction variable of urbanization and OFDI. Moreover, $\mu_{i t}$ is denoted with an error term.

\subsection{Estimation Strategy}

Firstly, this study has collected data from various sources, as mentioned in Table 1. After saturation of data, this study has applied the CD test to see whether each panel data is cross-sectional independent. By having the $C D$ for the proposed model, we have employed the slope of homogeneity. This approach is based on the estimation of delta $(\Delta)$ and the adjusted $\Delta$. After obtaining the standard outcomes, this study has used a secondgeneration econometrics unit root test, i.e., CIPS and CADF, as both tests are reliable when sample data confronts heterogeneity and $\mathrm{CD}$ issues [94]. After the integration of data, we used Westerlund cointegration to estimate the long-run cointegration among variables. To check out the long-term association among variables, the study used augmented mean group (AMG). The AMG approach considers heterogeneity and CD issues that are the main problems of panel data estimations. This method gives reliable results under heterogeneous panels with CD [95]. To check out the casual association among variables, this study has employed the bootstrap panel causality test, an advanced form of causality test.

This study's baseline model is constructed on five steps: the first step describes the CD test (Section 3.3.1). The second is the unit root test to measure the stationary variables (Section 3.3.2). The third is the cointegration panel estimation (Section 3.3.3). The fourth step consists of a long-run estimation technique known as AMG (Section 3.3.4). Finally, 
the study estimates the causality relationship through the bootstrap panel causality test (Section 3.3.5).

\subsubsection{Tests}

The essential step for estimation is to check the presence of $\mathrm{CD}$. In the most recent empirical analysis, estimation of $C D$ is the immediate attention of all researchers; unlike the traditional panel techniques, those assume the data as cross-sectional independence.

Hence, three tests, such as the CD test developed by Pesaran [96], Friedman [97], and Frees [98], are used to finalize an appropriate panel method, while the mathematical formulas of these are given in Equations (2)-(4).

$$
\begin{gathered}
\mathrm{CD}=\sqrt{\frac{2 T}{N(N-1)}}\left(\sum_{i=1}^{N-1} \sum_{j=i+1}^{N} \hat{\rho}_{i j}\right) N(0,1) \\
\mathrm{FRI}=(j-1)\left[\frac{2}{N} \sum_{i=1}^{N-1} \sum_{j=i+1}^{N} \gamma i j+1\right] \chi 2(j-1) \\
\mathrm{FRE}=\frac{(j-1)\left[\frac{2}{N} \sum_{i=1}^{N-1} \sum_{j=i+1}^{N} \gamma i j+\frac{1}{j}\right]}{S E(Q)} N(0,1) i, j
\end{gathered}
$$

The $\mathrm{CD}$ tests have the drawback of lacking power under a situation where pair-wise correlations are zero. To deal with this problem, Pesaran (2008) proposed the Lagrange multiplier (LM) test using the mean and variance of LM statistics. The bias-adjusted LM statistics are given as Equation (5):

$$
\mathrm{LM}_{a d j}=\sqrt{\frac{2 T}{N(N-1)}}\left(\sum_{i=1}^{N-1} \sum_{j=i+1}^{N} \hat{\rho}_{i j}\right)\left[\frac{(T-k) \hat{\rho}_{i j}^{2}-u T i j}{V(T-k) \hat{\rho}_{i j}^{2}}\right] N(0,1)
$$

where $K$ is denoted as a regressors, and $\hat{\rho}_{i j}^{2}$ and $u T i j$ are the mean and variance. Similarly, to test the slope homogeneity, Pesaran and Yamagata (2008) suggested the delta test that is valid for $(N, T) \rightarrow \infty$, and its hypothesis can be stated as Equation (6):

$$
\begin{gathered}
H \mathrm{o}: \beta i=\beta j \\
H 1: \beta i \neq \beta j \\
\Delta_{a d j}=\sqrt{N}\left[\frac{N-1 S-E(z i t)}{\sqrt{V(z i t)}}\right]
\end{gathered}
$$

Cross-sectional dimension $N$ could be relative to time $(t)$, where $E\left(z_{i t}\right)=k$ and $V\left(z_{i t}\right)=$ $2 k(T-k-1) /(T+1)$.

\subsubsection{Panel Units' Root Test}

To estimate the accurate outcomes, the first phase is to inspect the stationarity of variables. Widely accepted methods are often used, such as the Levin-Lin-Chu test by [99] and Im, Pesaran, and Shin (IPS) test by [100], but the drawback of these tests is that they cannot accounts the $\mathrm{CD}$, and rely on cross-sectional independence hypothesis. This study employs second-generation unit root tests, i.e., cross-augmented Dickey-Fuller (CADF) and augmented cross-sectional IPS (CIPS), to avoid the problem of CD. These tests are more robust than the conventional tests as these address the issues of $\mathrm{CD}$ and heterogeneity. The test statistics of CADF is expressed as Equation (7):

$$
\Delta X_{i t}=\Phi_{i}+\delta_{i} X_{i, t-1}+\gamma_{i} \bar{X}_{t-1}+\Psi_{i} \Delta \bar{X}_{t}+u_{i t}
$$


Here, $\bar{X}_{t-1}$ represents the mean across each cross-section. Further, the CIPS test can be presented as follows (Equation (8)):

$$
\mathrm{CIPS}=\frac{1}{N} \sum_{i=1}^{N} \delta_{i}(N, T)
$$

\subsubsection{Panel Cointegration Tests}

After examining variables' stationarity, the long-run association between variables can be identified by applying an error correction-based test [94]. Unlike traditional cointegration techniques, this test accounts for heterogeneity and autocorrelation and includes the stochastic shocks due to unobserved factors in panel data that simple methods cannot do. The dependency results might be weak or strong, but if ignored, they lead to inappropriate estimates. The cross-sectional error could result from standard shocks, spatial effects, and omitted common effects that can add $n$ error term. The practical form of Westerlund cointegration can be expressed as Equation (9):

$$
\Delta Y_{i t}=\delta_{i}^{\prime} d_{t}+\eta_{i}\left(Y_{i, t-1}-\beta_{i}^{\prime} x_{i, t-1}\right)+\sum_{j=1}^{p_{i}} \eta_{i j} \Delta y_{i, t-j}+\sum_{j=0}^{p_{i}} \gamma_{i j} \Delta x_{i, t-j}+u_{i t}
$$

Here, $\delta_{i}^{\prime} d_{t}$ and $\eta_{i}$ are the deterministic and coefficient of error correction terms. This test is based on two statistics, i.e., group $\left(G_{\tau}, G_{a}\right)$ and panel $\left(P_{\tau}, P_{a}\right)$. The null and alternate hypotheses can be expressed as:

$H_{\mathrm{o}}: \delta_{i}=0$

$H_{1}: \delta_{i}=\delta<0$ (for all $i$ )

The rejection of $H_{\mathrm{o}}$ means the entire panel is co-integrated. The cointegration presence is the symbol to proceed to the next estimation step, i.e., long-run relations between the variables. For this purpose, we employed panel estimation techniques to check the long-run association.

\subsubsection{Augmented Mean Group (AMG)}

The presence of cointegration among variables necessitates the requirement for checking the long-run association among the variables. To estimate the coefficient of explanatory variables, we found the long-run relationship with the AMG estimator. The primary advantage of using the AMG estimator is that it helps rectify panel heterogeneity and multifactor error terms. It is a long-run cointegration estimator developed for a moderate number of cross-sections and periods that provide robust results [101]. Another advantage of AMG is that it includes a time-invariant fixed effect in the model. It also consists of a common dynamic effect parameter. The AMG estimator was developed by Eberhardt and Bond [27] The AMG estimator employs a two-step method to estimate the unobserved and common dynamic effect and allows for CD by including the common dynamic effect parameter. First, it augments the equation with dummies and estimates with the first difference OLS, but it becomes bias if FD-OLS contains biasedness.

$$
\Delta y_{i, t}=\beta_{1 i}+\beta_{i} \Delta x_{i, t}+\varphi_{i} f_{t}+\sum_{t=2}^{T} \tau t D U M M Y t+u_{t}
$$

where $\Delta$ is the difference operator and $\tau$ is the coefficient of the time dummies and referred to as the common dynamic process [102]. Second, the group-specific regression model is augmented with an explicit variable or a unit coefficient imposed on each group member. The imposition of a unit coefficient is implemented by subtracting the AMG estimator from the dependent variable. Each regression includes an intercept that captures the time-variant fixed effect. The mean group estimator for AMG is obtained by,

$$
\mathrm{AMG}=N^{-1} \sum_{i=1}^{N} \beta i
$$

Furthermore, Phillips and Sul [103] proposed that when models face CD issues, heteroscedasticity, and serial correlation, panel estimators can result in misleading, inferior, 
and even inconsistent estimators, and here, the AMG can work appropriately. Likewise, AMG is flexible for the non-stationarity of variables in approximating the parameters [104].

\subsubsection{Bootstrap Panel Causality}

In the case of the presence of both CD among economies and country-specific heterogeneity, the most plausible panel technique is the bootstrap causality proposed by [27]. Likewise, AMG does not require any pre-testing, such as deciding the cointegration association between variables or investigating the stationarity [105]. Following Bond and Eberhardt [27], the optimal lag length is selected to minimize the Schwarz Bayesian criterion. For instance, in the case of investigating the causal association between environmental quality and other selected indicators with OFDI and HDI, the testing procedure can be written as follows,

$$
\begin{gathered}
\mathrm{CFP}_{1 t}=\alpha 11+\sum_{k=1}^{n 1} \delta 11 k \mathrm{CFP} 1 t-k+\sum_{k=1}^{n 1} \sigma 11 k \mathrm{EC} 1 t-k+\mu_{11 t} \\
\mathrm{CFP}_{N t}=\alpha 1 N+\sum_{k=1}^{n 1} \delta 11 k \mathrm{CFP} N t-k+\sum_{k=1}^{n 1} \sigma 11 k \mathrm{ECN} t-k+\mu_{1 N t} \\
\mathrm{EC}_{1 t}=\alpha 11+\sum_{k=1}^{n 1} \delta 21 k \mathrm{CFP} t-k+\sum_{k=1}^{n 1} \sigma 21 k \mathrm{EC} 1 t-k+\mu_{11 t} \\
\mathrm{EC}_{N t}=\alpha 1 N+\sum_{k=1}^{n 1} \delta 2 N k \mathrm{CFP} N t-k+\sum_{k=1}^{n 1} \sigma 2 N k \mathrm{ECN} t-k+\mu_{1 N t}
\end{gathered}
$$

$N$ implies the number of countries, $k$ implies the time, and $i$ refers to lag length criteria. CFP denotes carbon footprint, and EC denotes indicators of ED.

Since the Granger causality test results may be sensitive to the lag structure, determining the optimal lag length is crucial for robustness. For relatively large panel variables, varying the lag structure would substantially increase the computational burden. To remove this problem following bootstrap panel causality, we allow maximal lags to differ across the variables, but it would be the same across the equations; if this does not follow the bootstrap panel, causality will be inappropriate.

\section{Results and Discussion}

\subsection{Descriptive Statistics}

Before econometric model outcomes, it is necessary to understate the integrating properties of the sample data. Table 2 provides the variables' descriptive statistics in terms of mean, median, maximum, minimum, standard deviation, and Jarque-Bera (J-B) statistics. According to the empirical values given in the table, technology has the lowest while CFP has the highest mean value. It means the values of greenhouse gas emissions remain high. In the selected variables, the degree of variability of OFDI from mean values is highest. The values of the kurtosis and Jarque-Bera test confirm that all the variables are normally distributed. Likewise, Table 2 represents CFP, OFDI, URB, TECH, TO, and NR deviate from the mean value by $0.516,0.866,0.078,0.149,0.530,0.246$, and 0.445 , respectively. Overall, there is not a large difference between mean and median values, and it shows that our data do not have any outliers.

Table 2. Descriptive statistics.

\begin{tabular}{cccccccc}
\hline & LCFP & LOFDI & LHDI & LURB & LTECH & LTO & LNR \\
\hline Mean & 5.8640 & 4.2228 & 0.6613 & 0.3977 & -8.5538 & -0.2516 & 0.4359 \\
Median & 5.7317 & 4.4141 & 0.6660 & 0.3828 & -8.6067 & -0.2786 & 0.4975 \\
Maximum & 7.1702 & 6.2972 & 0.8070 & 0.7060 & -7.5290 & 0.3432 & 1.4127 \\
Minimum & 4.9834 & 1.9345 & 0.4310 & 0.0878 & -9.7249 & -0.8193 & 0.9094 \\
Std. Dev. & 0.5162 & 0.8668 & 0.0783 & 0.1494 & 0.5303 & 0.2640 & 0.4452 \\
Skewness & 0.6429 & -0.3390 & -0.5616 & 0.0923 & -0.1117 & 0.2279 & -0.6386 \\
Kurtosis & 2.6250 & 2.5349 & 3.1264 & 2.8078 & 2.1881 & 2.6696 & 3.0121 \\
Jarque-B & 21.3037 & 8.0272 & 15.1732 & 0.8433 & 8.4206 & 3.7637 & 19.3731 \\
Probability & 0.0000 & 0.0181 & 0.0005 & 0.6560 & 0.0148 & 0.1523 & 0.0001 \\
\hline
\end{tabular}

Table 3 shows that OFDI has a statistically significant and positive correlation with CFP, which means that the level of CFP will increase if there is an increase in OFDI. Similarly, 
there is a negative association between the HDI and explained variable at a $5 \%$ level of significance, which implies that a rise in human well-being (HDI) will decline the level of CFP. Likewise, urbanization has a significantly positive correlation with CFP at a $1 \%$ level of significance; economically, we can say, a rise in urbanization will increase the level of CFP. In addition, technology and TO negatively correlate with the dependent variable at a $5 \%$ significance level, which means that an increase in these variables will cause a decline in environmental damages. Moreover, NR has a positive and significant impact and increases the CFP level. In terms of correlation among the variables, there is a higher degree of correlation among the selected variables. This evidence suggests no possible collinearity, which could affect the identification of parameters in the model. However, correlation does not necessarily imply causalities, and therefore, this study test the causalities among variables. Likewise, analysis confirms that there is no multicollinearity (see Appendix A, Table A3 for details). Descriptive details of the first and last year of the panel for selected dependent and independent variables are also presented in Appendix A, Table A4.

Table 3. Pair-wise matrix correlation.

\begin{tabular}{cccccccc}
\hline & LCFP & LOFDI & LHDI & LURB & TECH & LTO & LNR \\
\hline LCFP & 1 & & & & & & \\
LOFDI & $0.4442^{* *}$ & 1 & & & & \\
HDI & $-0.1941^{* *}$ & $0.6334^{* * *}$ & 1 & & & \\
LURB & $0.1465^{* * *}$ & $-0.2637^{* *}$ & $-0.350^{* * *}$ & 1 & & 1 \\
TECH & $-0.7795^{* *}$ & $-0.3876^{* *}$ & $0.067^{* * *}$ & $0.2050^{* *}$ & 1 & \\
LTO & $-0.5632^{* *}$ & $-0.054^{* * *}$ & $0.395^{* * *}$ & $0.2076^{* * *}$ & $0.5867^{* *}$ & 1 \\
LNR & $0.2028^{* * *}$ & $0.2560^{* * *}$ & $0.0714^{* * *}$ & $0.2959^{* * *}$ & $0.0913^{* * *}$ & $0.2419^{* * *}$ & 1 \\
\hline
\end{tabular}

Note: ${ }^{* *}$ and ${ }^{* * *}$ show the level of significance at $5 \%$ and $1 \%$.

\subsection{Ratio Tests}

In this segment, findings of the $\mathrm{CD}$ test are described (Table 4). The above-stated results approve our initial perception since the different tests can vehemently reject the $\mathrm{H}_{0}$ of cross-sectional independence for the selected panel. As a result, the selected panel showed $\mathrm{CD}$, and thus second-generation unit root and cointegration tests that accommodate the $\mathrm{CD}$ should be used. In addition, findings of the test for homogeneity are also given in the lower panel of Table 4 . The obtained values meet the standard criteria of the homogeneity test.

Table 4. CD and homogeneity test.

\begin{tabular}{|c|c|c|c|c|c|c|}
\hline \multicolumn{4}{|c|}{ Model 1} & \multicolumn{3}{|c|}{ Model 2} \\
\hline & & Value & $p$-Value & & & $p$-Value \\
\hline \multicolumn{4}{|c|}{ LCFP = f(LOFDI, LHDI, LTEC, LURB, LTO, LNR) } & \multicolumn{3}{|c|}{$\begin{array}{c}\text { LCFP }=\mathrm{f}(\text { LOFDI, LFD.HDI, LFD.TEC, LFD.URB, } \\
\text { LFD.TO, LFD.NR) }\end{array}$} \\
\hline \multicolumn{2}{|c|}{ Pearson (CD) } & \multicolumn{2}{|l|}{4.767} & \multicolumn{2}{|c|}{4.617} & 0.000 \\
\hline \multirow{2}{*}{\multicolumn{2}{|c|}{$\begin{array}{c}\text { Frees }(Q) \\
\text { Friedman }(C D)\end{array}$}} & 1.700 & 0.051 & \multicolumn{2}{|c|}{1.778} & 0.005 \\
\hline & & 51.611 & 0.000 & \multicolumn{2}{|c|}{50.756} & 0.000 \\
\hline \multicolumn{4}{|c|}{ LCFP = f(LOFDI, LHDI, LTEC, LURB, LTO, LNR) } & \multicolumn{3}{|c|}{$\begin{array}{c}\text { LCFP }=\mathrm{f}(\text { LOFDI, LFD.HDI, LFD.TEC, LFD.URB, } \\
\text { LFD.TO, LFD.NR) }\end{array}$} \\
\hline \multicolumn{2}{|r|}{ Delta } & \multicolumn{2}{|c|}{ adj. } & Delta & \multicolumn{2}{|c|}{ adj. } \\
\hline \multirow{2}{*}{$\begin{array}{c}\text { Statistics } \\
(p \text {-value) } \\
\text { D.V }\end{array}$} & $6.845(0.000)$ & \multicolumn{2}{|c|}{$7.904(0.000)$} & $5.360(0.000)$ & \multicolumn{2}{|c|}{$6.189(0.000)$} \\
\hline & LM & LM adj & LM CD & LM & LM adj & LM CD \\
\hline $\begin{array}{l}\text { Statistics } \\
(p \text {-value })\end{array}$ & $112(0.000)$ & $13.88(0.000)$ & $5.139(0.000)$ & $114.7(0.000)$ & $14.54(0.000)$ & $5.442(0.000)$ \\
\hline
\end{tabular}

\subsection{Second-Generation Unit Root Tests}

Table 5 presents the detailed findings of the unit root tests. For the sampled economies, the CADF test results show that LCFP and LTEC are stationary at level, while LHDI, LOFDI, 
LURB, LTO, and LNR are stationary at first difference. On the other hand, the results of CIPS also do not significantly vary from the CADF findings.

Table 5. CIPS and CADF unit root test.

\begin{tabular}{|c|c|c|c|c|}
\hline \multirow{2}{*}{ Variables } & \multicolumn{2}{|c|}{ CADF } & \multicolumn{2}{|c|}{ CIPS } \\
\hline & Level & 1st Diff. & Level & 1st Diff. \\
\hline LCFP & $-3.338^{* * *}$ & -1.957 & $-3.838^{* * *}$ & -2.574 \\
\hline LHDI & -1.236 & $-3.350 * * *$ & -1.996 & $-3.254^{* *}$ \\
\hline LOFDI & -1.171 & $-4.434^{* * *}$ & -1.962 & $-4.852^{* * *}$ \\
\hline LURB & -1.965 & $-3.075^{* * *}$ & -1.965 & $-2.694^{* * *}$ \\
\hline LTEC & $-2.456^{* * *}$ & -3.429 & $-2.456^{* *}$ & -3.456 \\
\hline LTO & -1.818 & $-5.985^{* * *}$ & -1.576 & $-3.867^{* * *}$ \\
\hline LNR & -2.083 & $-4.767^{* * *}$ & -2.083 & $-3.996^{* * *}$ \\
\hline
\end{tabular}

\section{Westerlund Panel Cointegration Tests}

This section presents the cointegration association results between the variables in the model by using Westerlund's error correction model [94] for cointegration as this method is consistent with data sets. Table 6 represents the result of the cointegration by including constant and trend values. The model and countries show that $G_{t}$ and $P_{t}$ test statistics reject $\mathrm{H}_{0}$ of no cointegration with bootstrapped $p$-values at one and five percent. For instance, the cointegration vectors are conformed for both models. The resulting output implies a cointegration association between all concerned variables, as explained in the study model.

Table 6. Westerlund cointegration test.

\begin{tabular}{ccccc}
\hline Statistic & \multicolumn{1}{c}{ Value } & Z-Value & $p$-Value & Robust $\boldsymbol{p}$-Value \\
\hline \multicolumn{5}{c}{ LCFP $=\mathrm{f}($ LOFDI, LHDI, LTEC, LURB, LTO, LNR) } \\
$\mathrm{G}_{\mathrm{t}}$ & -14.835 & 5.856 & 0.000 & \\
$\mathrm{G}_{\mathrm{a}}$ & 4.897 & 6.930 & 1.000 & 0.000 \\
$\mathrm{P}_{\mathrm{t}}$ & -1.014 & 9.374 & 1.000 & 0.590 \\
$\mathrm{P}_{\mathrm{a}}$ & -3.963 & 5.843 & 1.000 & 1.000 \\
& $\mathrm{LCFP}=\mathrm{f}(\mathrm{LOFDI}, \mathrm{LFD} . H D I$, LFD.TEC, LFD.URB, LFD.TO, LFD.NR) & 0.005 \\
$\mathrm{G}_{\mathrm{t}}$ & -2.032 & 3.884 & 1.000 & 0.007 \\
$\mathrm{G}_{\mathrm{a}}$ & -1.253 & 6.522 & 1.000 & 0.256 \\
$\mathrm{P}_{\mathrm{t}}$ & -4.085 & 5.283 & 1.000 & 0.025 \\
$\mathrm{P}_{\mathrm{a}}$ & -2.116 & 5.143 & 1.000 & 0.790 \\
\hline
\end{tabular}

\subsection{Long-Run Estimated Results by AMG Technique}

This section is separated into two different sections:

(1) Country-wise results;

(2) Results related to panel estimation for NIC.

\subsubsection{Country-Wise Estimated Results}

The AMG analysis is divided into two parts, the main effect, and the interaction effect. The findings of both main and interaction effects are given in the following Table 7 . The upper panel validates the model with main effects, and the lower panel shows the model with an interaction term. In fact, without the interaction term, OFDI is proposed to have a positive and statistically significant effect on CFP in Brazil, China, and South Africa (0.4986, 0.0861 , and 0.1356), while the negative and significant impact in Indonesia, Mexico, and Turkey $(-0.1482,-0.039,-0.073)$. The increase in OFDI plays a driving role in footprint; a $1 \%$ rise in OFDI promotes the CFP by $0.4986 \%, 0.0861 \%$, and $0.1356 \%$ in Brazil, China, and South Africa. These results are in line with the study of Cai et.al. [106]. It seems that concerned economies have not transferred from energy-intensive industries through OFDI. 
Maybe there are two possible reasons to explain this statement: Concerned economies' OFDI has the feature of resource seeking, which lacks advanced technology, making it difficult to form positive environmental technology feedback to raise ED [49]. Further, the increase in OFDI would indorse a rise in the second industry with high carbon emissions due to the high energy consumption. Likewise, the coefficient of OFDI influences the explained variable negatively and passes the significance test. This can be due to the lack of policy barriers by the local governments for the region's economic development, and they encourage industrial capital outflows. Consequently, concerned economies have the success to transfer high polluting enterprises out.

Another determinant of environmental quality used by this study is HDI. Without the interaction term, economic development significantly influences enhancing CFP in China, India, Indonesia, Mexico, and Thailand, while this impact was negative for the Philippines. This negative impact can be due to HDI that improves the environmental quality as rising carbon emissions levels force policymakers to focus on green and clean energy to gain environmental sustainability. In addition, the introduction of the interaction term OFDI.HDI harms environmental quality in China, Indonesia, and Thailand. The estimation results revealed that CFP for China, India, Indonesia, Mexico, and Thailand, to some extent, follows the increasing trend for economic development level, thus approving the scale effect. Hence in such economies, the OFDI spillover effect through education, training, and skills promotes human well-being and improves environmental quality, which is in contrast with the findings of [107].

In the case of urbanization with the main effect, it is impacting CFP in many NIC economies (Brazil (0.4558), India (0.4936), and South Africa (0.026)). However, blind expansion and transformation of cities have caused environmental pollution, although urbanization can increase people's affluence. Therefore, policymakers should encourage green and sustainable urbanization to boost economic growth without ED. For China's case coefficient value is negative $(-0.1609)$, which can be due to the fact that the government proposes balancing the urban population and further reducing the pressure of urbanization. However, the interaction term of OFDI.URB indicates the negative association between urbanization and environmental quality for Brazil, China, India, Indonesia, Mexico, and Turkey. According to the research outcome, studies rate urban population as a negative factor concerning CFP [108-110], and other researchers state that urbanization positively contributes to environment quality [111-113]. Our findings detect both negative and positive effects on urbanization and conflict with panel and time-series analysis studies, and this discrepancy can be attributed to the heterogeneity across the NIC economies. Study findings demonstrate that urbanization can reduce environmental damages by transitioning from rural to urban areas. Improvements in the urbanization level parallel a switch in energy use, accompanying the transition from traditional fuels to a modern energy source [114].

Subsequently, we focused on the technology-emissions nexus. The coefficient of technology has a positive and significant influence on the environment quality in the case of China (0.233) and Thailand (0.316), while it harms Malaysia (-0.137) and Turkey $(-0.139)$. In China and Thailand, ED is increasing due to technology expansion, which may be due to the rise in usage of traditional energies. In Malaysia and Turkey, energy-related technologies shift from traditional energies to clean and green energies, which cause a further rise in energy efficiency. Likewise, the interaction term of technology and OFDI indicates the negative effect of technology on emissions (CFP) in Brazil, China, Indonesia, Malaysia, the Philippines, and Turkey. Therefore, the spillover effect of OFDI toward the technology cause to increase in environment quality via efficient use of technology and new eco-friendly techniques.

Another determinant of CFP is TO, and it has a significant negative influence on the environment in China and Malaysia. Similarly, the relevant interaction term, TO.OFDI also has a negative and significant impact on carbon emissions in several nations, i.e., Brazil, China, India, Malaysia, the Philippines, and Turkey. TO is negatively associated with ED 
with interaction and without interaction terms; this implies that TO lowers the energy demand, reducing environmental damages (CFP), as concerned economies' production is majorly dependent on the traditional energy source. The positive impact of TO on the CFP relationship coincides with the results of Zhang and Zhang [115] and Shahbaz et al. [116]. Moreover, these outcomes may be due to the governments' more attention to environmental quality by drawing lessons from industrialized economies. As trade-based economies, the NICs should encourage clean production and imports of clean goods and services to raise the spillover effect of OFDI.

For the case of NR, results show that every $1 \%$ rise upsurges the level of CFP by $0.055 \%$ for China, $0.127 \%$ for Malaysia, and $0.048 \%$ for Thailand, while at the same time, NR will decrease the level of CFP by $0.396 \%$ for Indonesia, and $0.025 \%$ for Mexico, respectively. Using the interaction variable of NR and OFDI, we found a negative association between the explained and interaction term for Brazil, China, Malaysia, Mexico, Philippines, and Thailand. The negative coefficient of NR for Indonesia and Mexico may be due to additional natural resources that are backing up to mitigate the ED. Moreover, these findings are linked with the employment of own energy sources, which produces fewer greenhouse gas emissions than fossil fuels $[117,118]$. Instead, the role of NR in raising the CFP of China, Malaysia, and Thailand is related to economic development in industrialized nations, hastening NR abstraction and unsustainable use, and aggregating the economy's reliance on fossil fuel imports. The traditional energy sources are finite and unsustainable, which clues to an increase in ED.

Table 7. Country-wise AMG results.

\begin{tabular}{|c|c|c|c|c|c|c|}
\hline Countries & LOFDI & HDI & LURB & LTEC & LTO & LNR \\
\hline \multicolumn{7}{|c|}{ LCFP = f(LOFDI, LHDI, LTEC, LURB, LTO, LNR) } \\
\hline Brazil CFP & 0.4986 * & 0.7621 & $0.4583296 * *$ & 0.2951888 & -0.6987173 & 0.1915813 \\
\hline China CFP & $0.0816^{* * *}$ & $4.9810 * * *$ & $-0.1609404 * *$ & $0.2336264^{* * *}$ & $-0.0952421 *$ & $0.0552845 * * *$ \\
\hline India CFP & -0.00047 & $3.43107^{* * *}$ & $0.4936958^{* * *}$ & 0.0779479 & -0.0644734 & -0.0002674 \\
\hline Indonesia CFP & $-0.1482 * *$ & $7.391345^{* *}$ & -1.202482 & -0.1194937 & -0.5738239 & $-0.3961924^{* *}$ \\
\hline Malaysia CFP & 0.00493 & -1.356482 & 0.4993489 & $-0.1373283 *$ & $-0.5676649^{* * *}$ & $0.1272716^{* *}$ \\
\hline Mexico CFP & $-0.0398 * *$ & 2.392493 * & 0.1783463 & 0.0280996 & 0.0495174 & $-0.0250876^{* * *}$ \\
\hline Philippines CFP & -0.0098 & $-7.356229 * * *$ & -0.0337455 & -0.1691313 & 0.1483492 & -0.0586668 \\
\hline South Africa CFP & $0.1356 * *$ & -0.224603 & $0.0267689 *$ & 0.0526981 & 0.0274314 & -0.009741 \\
\hline Thailand CFP & $0.1818^{* * *}$ & $3.285365^{* *}$ & -0.0995152 & $0.3163916^{* * *}$ & -0.0843092 & $0.0480318^{* *}$ \\
\hline Turkey CFP & $-0.0735^{* *}$ & 0.2644049 & -0.0214476 & $-0.1399135^{* * *}$ & 0.0856674 & 0.0084279 \\
\hline \multicolumn{7}{|c|}{ LCFP = f(LOFDI, LFD.HDI, LFD.TEC, LFD.URB, LFD.TO, LFD.NR) } \\
\hline Brazil CFP & $-2.383383 * * *$ & $2.836309 * *$ & $-0.4027657^{* * *}$ & $-0.1831603 * *$ & $-0.6104831 * *$ & $-.2165897 * * *$ \\
\hline China CFP & $-2.712502 * * *$ & $-0.973503 * * *$ & $-1.279537 * *$ & $-1.168911^{* * *}$ & $-0.1563365 * *$ & $-0.1293574 * * *$ \\
\hline India CFP & $-2.48038^{* * *}$ & $3.305559 * * *$ & $-0.6542659 * * *$ & 0.0085439 & $-0.2619901^{* * *}$ & .0640744 \\
\hline Indonesia CFP & -4.310358 & $-3.712003 * *$ & $-1.187388 *$ & $-0.6051151^{* *}$ & -0.0161682 & -0.1355694 \\
\hline Malaysia CFP & -0.5997902 & 1.237373 & 0.1037203 & $-0.3054977 * *$ & $-0.5789459 * * *$ & $0.1934171^{* *}$ \\
\hline Mexico CFP & $-4.257654^{* * *}$ & $3.848648 * *$ & $-0.3057695^{* * *}$ & -0.0193431 & 0.1145376 & $-0.0284495^{* *}$ \\
\hline Philippines CFP & -1.332859 & 1.700264 & -0.1653766 & -0.2981132 * & $-0.1138411^{* *}$ & $-0.0625026^{* *}$ \\
\hline South Africa CFP & 0.8461718 & -0.6866525 & -0.1206431 & 0.0155168 & 0.2639024 & -0.0343194 \\
\hline Thailand CFP & -1.759052 & $-1.619429 *$ & -0.0965558 & 0.069417 & 0.2393592 & $-0.0126298 *$ \\
\hline Turkey CFP & $-2.186035^{* * *}$ & $2.29286^{* * *}$ & $-0.1399298 * *$ & $-0.1052911^{* * *}$ & $-0.0714231^{* *}$ & 0.0178704 \\
\hline
\end{tabular}

Note: ${ }^{* *}$, and $* * *$ shows the level of significance at $10 \%, 5 \%$, and $1 \%$.

\subsubsection{Long-Run Results of AMG (Panel)}

Table 8 reports the AMG findings and describes the impact of OFDI and selected indicators on the CFP. According to the findings of model 1, OFDI has a significantly positive effect on ED, implying that every 1\% increase in OFDI would increase environmental damage by $0.063 \%$. This outcome can be explained with a brief discussion. An increase in OFDI will decrease environmental quality in NIC economies, proving the absence of OFDI reverse technology overflow. After expanding FDI, domestic enterprises may enhance their energy consumption by using traditional technologies of the domestic economy and ultimately augment ED. This study has practical implications for controlling the environmental damages, particularly relating to OFDI. Presently, the NIC economies have supported their domestic firms through investing overseas to expand foreign markets and benefit domestic 
economic growth. That is to say, OFDI exerts pollution haven effects that increase the NIC's environmental damages. Thus, governments should be careful about the impact of OFDI on environmental quality. It argues that OFDI shifts productive capital abroad, generates no benefit to the home country, and cannot transfer green technology spillover back to the home economies through the main impact of environmental regulations, and these findings are in line with the works of $[20,119]$.

While in the second model, OFDI with the interaction model shows a negative impact, which means a $1 \%$ increase in this factor would decline CFP by $2.117 \%$. A rise in the level of OFDI significantly decreases greenhouse gas emissions and advances the environmental quality, and this result is steady with the case study of China by [25]. Before the interaction term model measurement, the OFDI coefficient is positive and significant. After adding the interaction term, the above-stated coefficient became negative and highly significant, which depicts that overseas investment expands the local market share or gives high energy, which has little effect on the environmental pollution of the domestic economies. An increase in OFDI reverses the technology spillover effect generated by the enterprises, improves the factor productivity of home-based enterprises, including energy use efficiency, and reduces pollution emissions. Due to this action, the rise in OFDI can effectively improve the environmental quality in NIC economies.

Likewise, HDI is a proxy of economic development that is another determinant of $\mathrm{ED}$, and it has been neglected in the existing literature. The given coefficient value (1.357) of HDI without interaction term is positively and statistically significant. This explains that any action to improve human well-being has a positive influence on the ED. In other words, policies to promote social welfare will pose severe environmental challenges, as found in several earlier studies [120-122]. On the other hand, the interaction termHDI.OFD shows the moderating role of OFDI with HDI that is negatively associated with ED. This infers that every $1 \%$ increase in this factor would cause to decline in ED by $2.283 \%$ for the concerned economies. From this outcome, we conclude that HDI with interaction terms can improve the environment quality, which may occur due to the spillover effect of OFDI in the domestic economy. Thus, more and more OFDI with human well-being will lead to a sustainable environment.

The study also examines the role of urbanization. A $1 \%$ increase in urbanization would cause a decline in the CFP by $0.084 \%$. Several logics can be behind this association: Firstly, population concentration contributes to manufacturing agglomeration and makes the economic system and distribution of resources more competitive and rational [123]. Secondly, the agglomeration of qualified persons in urbanization promotes technological innovation through learning, imitational, and spillover effects and improves production efficiency. Thirdly, concerning economies are reducing ED via improvement in technology and energy efficiency. Consequently, rapid urbanization leads to economic growth and an indirect rise in carbon emissions [124]. This is in conformity with earlier studies in the context of different regions such as Liu and Bae [125], Wang et al. [126], and contrasted with Pata [127].

Likewise, the inclusion of the term OFD.URB indicates the association between CFP and urbanization. Outcomes depict that the moderating role of OFDI with urbanization on CFP is positive and insignificant. Thus, due to the insignificant $p$-value (0.756), there is a need to discuss it more in detail. This finding supports the argument that depending on the estimation technique, urbanization could have either negative or positive effects on emissions [128]. In line with the claim made by the authors of [129], the negative or positive effects of urbanization on carbon emissions are consistent with the ecological modernization and environmental transition theories, and it is challenging to determine urbanization's net impact on the quality of the environment. So urbanization can have both effects on the environment quality in different scenarios.

As one would expect, technology has a palpable effect on the CFP, with an approximate value of 0.043 . Statistically, it implies that all other remains the same; every $1 \%$ rise in the aforementioned variable enhances ED by $0.043 \%$, and these results are steady with the 
USA case study [130]. Based on this, we can say that technology is one of the crucial and significant factors influencing the emissions level, and NICs' policymakers should focus on improved technologies. Contrary, model 2 shows the negative association between the interaction variable (OFDI.TEC) and CFP, keeping all else the same. Specifically, a 1\% rise in the aforesaid variable would cause a reduction of $0.088 \%$ in $\mathrm{ED}$, and these findings are consistent with the literature [131,132]. Therefore, countries with higher technology levels and improved infrastructure attract less polluted investment and shift their unclean technology to economies with lower environmental standards.

As mentioned, TO is being considered as another determinant of ED. According to model 1, the given eco-efficient value $(-0.177)$ is statistically significant at a $1 \%$ level and negatively correlated with CFP, infers that every $1 \%$ rise in this factor would decline ED by $0.177 \%$ through lower energy demand and fewer carbon emissions. Furthermore, the finding contradicts the common perception that TO increases economic growth and contributes positively to energy consumption. More specifically, trade liberalization will increase income for investment and the use of energy-efficient technologies. This finding is in line with the study of China [116], a study related to India [117], the study of 182 economies by Wang and Zhang [133], the study of India by Nepal et al. [134], and a case study of OCED economies by Gozgor [135].

In model 2, the impact of TO with the interaction term of OFDI has not variated from the main effect. The coefficient value of FD.TO $(-0.082)$ is negatively correlated with explained variable (CFP). Keeping other things constant, a $1 \%$ rise would cause to diminish environmental damages by $0.082 \%$, and therefore a tendency for TO to decrease emissions is the same for the interaction term. This can be attributed to the spillover effect of FDI, as the economies' technical capacity gradually improves due to the inflow of foreign capital and exposure to advanced management practices. Our outcomes are consistent with Shahbaz et al. [136] and Reyes et al. [137] and in contrast with the findings of several earlier studies [138-140].

Finally, we discovered interesting patterns regarding NR and results reveal that a single percent increase in its level may decline CFP by $0.005 \%$ by holding all others the same. Still, results confirm that NR reduces ED in NIC countries. The transition from outdated technologies that cause NR exploitation to advance ones that integrate recycling, reprocessing, and value addition to substitute NR will lead to more GDP and improve environmental quality [72]. Of particular importance is the fact that the interaction variable (NR.OFDI) provided an opposite result and exposed the positive association with environmental quality. Specifically, every $1 \%$ rise in this interaction variable would increase ED by $0.037 \%$, which implies that more pressure on the NR to achieve high GDP may threaten the quality of the environment in the long run. In line with the previous literature [141], the empirical outcomes state that NR positively relates to CFP, indicating that private investment leads to more carbon emission.

Additionally, considering the statistical output, an increase in NR would increase the ED. The finding for the impact of FD.NR term on CFP points out extraction, and unsustainable use of NR as NIC region mainly rely on energy imports (oil, gas) to meet their energy requirements instead of using renewable energy sources, i.e., water, air, and solar. Countries are consuming NR unsustainably for gaining economic benefits, and poor resource management is one reason for the injudicious use of these limited resources [92]. In oppose, moving from outdated to modern technologies (that integrate recycling, innovations, value addition) will help in reducing ED through less carbon emission [72]. 
Table 8. Panel estimated results by AMG technique.

\begin{tabular}{ccccc}
\hline Variable & Coefficient & St. Error & Z-Value & $p$-Value \\
\hline & LCFP $=\mathrm{f}($ LOFDI, LHDI, LTEC, LURB, LTO, LNR) & \\
LOFDI & 0.0630 & 0.0573 & 1.10 & 0.022 \\
LHDI & 1.3570 & 1.2735 & 1.07 & 0.000 \\
LURB & -0.0849 & 0.1544 & -0.55 & 0.001 \\
LTEC & 0.0438 & 0.0590 & 0.74 & 0.039 \\
LTO & -0.1773 & 0.0987 & -1.80 & 0.003 \\
LNR & -0.0059 & 0.0493 & -0.12 & 0.014 \\
Cons. & 5.1719 & 0.4287 & 12.06 & 0.000 \\
& LCFP $=\mathrm{f}($ LOFDI, LFD.HDI, LFD.TEC, LFD.URB, LFD.TO, LFD.NR) & \\
LOFDI & -2.1175 & 0.4919 & -4.30 & 0.000 \\
LFD.HDI & -2.2839 & 0.4347 & -5.25 & 0.000 \\
LFD.URB & 0.05433 & 0.0887 & 0.35 & 0.756 \\
LFD.TEC & -0.0887 & 0.0780 & -1.14 & 0.005 \\
LFD.TO & -0.0820 & 0.0995 & -0.82 & 0.051 \\
LFD.NR & 0.0373 & 0.0358 & 1.04 & 0.002 \\
Cons. & 5.0696 & 0.6637 & 7.64 & 0.000 \\
\hline
\end{tabular}

\subsection{Results of Bootstrap Panel Causality}

Along with the long-run relationship between selected variables, it is imperative to know the casual links running among the selected indicators of environmental quality. The present study relies on the latest developed bootstrap panel causality test that advances the version of the Granger causality by [27]. The direction of causality assists the policymakers in regulating appropriate economic policies along with the economic strategies in the selected economies. Bootstrap panel causality test results are given in Table 9. The direction and sign of causality can be identified from the significance level of anticipated variables.

The results expose that the long-run bidirectional causality exists between urbanization and CFP. The direction of causality shows that the CFP causes urbanization, and any improvement in the level of urbanization sector will cause CFP, and these results are consistent with $[142,143]$ and in contrast with [144]. These outcomes imply that urbanization is an important factor for the environment, and it cannot be omitted from the environment quality models. Slowing down the urbanization growth while remaining other things constant could be a governments' option to meet an environmental target. On the other hand, it may not be a suitable option because the urbanization level of economies reflects the country's level of economic performance. Thus, the governments of specified economies should adopt such policies that can improve the environment quality by having sustainable urbanization.

Likewise, the same behavior has been observed for human well-being and CFP, implying ED affects the human development process; conversely, low human development causes ED. This outcome is in line with Wang [145] and Akbar et al. [146]. Likewise, this feedback hypothesis implies that ED significantly deteriorates human well-being in concerned economies due to a rise in health issues.

In addition, the results also support the bidirectional causality between urbanization and human well-being. This means that any fluctuation in urbanization reflects human well-being immediately, while HDI stimulates the urbanization level in the long run. In other words, policies relevant to urbanization and HDI are working jointly. All policies related to urbanization and human well-being should be efficient for attaining extended support, as urbanization triggers more job opportunities and better health facilities, and this finding is consistent with [147].

The bootstrap panel causality results reveal that there is two-way causality running between TO and technology. The feedback relationship from TO to technology shows that variation in $\mathrm{TO}$ can significantly affect technology, implying more progress in $\mathrm{TO}$ is responsible for the higher level of technology in NIC economies. The liberalization of the economy during the estimated period has ensured much trade flows in and out 
of the economies, and this has induced technological innovation in the country coming through imports. This has created a more competitive domestic market and enhances the demonstration and imitation effects by domestic firms. The enhanced competitiveness of domestic firms and improved demonstration, learning, and imitation effect of TO have increased the efficiency of the export sector. The concerned causal relationship shows that energy efficiency will rise due to the import of advanced technology. In simple words, technology and TO are interconnected, and an upsurge in TO will affect the level of technology, and these results are concurrent with several past studies [148-150].

Similarly, the results indicate that NR can significantly cause variation in the level of TO in the selected region, while the feedback relationship from TO to NR shows that any fluctuation in TO will affect the level of NR. Thus, both TO and NR are interlinked, as in the mentioned panel; NR is dependent on TO. Based on this outcome, newly industrialized policymakers should address the long-run positive shock and focus on trade liberalization policies. Positive effects from the positive shocks to TO will attract investment, human capital, and technology transfer.

Whereas the one-way causality runs from OFDI to CFP, this implies that OFDI is harmful to the environmental situation. Likewise, unidirectional causality is running from CFP to technology and TO. Furthermore, OFDI Granger causes HDI, TO, and NR, and HDI causes NR. In addition, a graphical representation of bootstrap panel causality is presented in Appendix B, Figure A1.

Table 9. Bootstrap panel causality results.

\begin{tabular}{cccc}
\hline Variable & W-Bar & Z-Bar $(p$-Value $)$ & $p$-Value \\
\hline LCFP $\gg$ LOFDI & 4.7686 & 7.0847 & $(0.200)$ \\
LOFDI $\gg$ LCFP & 4.7193 & 6.9897 & $(0.052)$ \\
LCFP $\gg$ LHDI & 6.5639 & 10.539 & $(0.227)$ \\
LHDI $\gg$ LCFP & 2.2971 & 2.3286 & $(0.190)$ \\
LCFP $\gg$ LURB & 5.3430 & 8.1899 & $(0.000)$ \\
LURB $\gg$ LCFP & 2.9434 & 3.5724 & $(0.007)$ \\
LCFP $\gg$ LTEC & 4.2081 & 7.1735 & $(0.540)$ \\
LTEC $\gg$ LCFP & 1.8805 & 1.9688 & $(0.020)$ \\
LCFP $\gg$ LTO & 3.9474 & 6.5906 & $(0.700)$ \\
LTO $\gg$ LCFP & 1.4282 & 0.9574 & $(0.880)$ \\
LCFP $\gg$ LNR & 0.8690 & -0.2929 & $(0.390)$ \\
LNR $\gg$ LCFP & 1.6740 & 1.5071 & $(0.000)$ \\
LOFDI $\gg$ LHDI & 5.5196 & 8.5298 & $(0.870)$ \\
LHDI $\gg$ LOFDI & 2.3306 & 2.9753 & $(0.130)$ \\
LOFDI $\gg$ LURB & 2.5494 & 3.4646 & $(0.800)$ \\
LURB $\gg$ LOFDI & 3.2849 & 5.1092 & $(0.190)$ \\
LOFDI $\gg$ LTEC & 2.6775 & 3.7510 & $(0.180)$ \\
LTEC $\gg$ LOFDI & 3.9161 & 6.5207 & $(0.040)$ \\
LOFDI $\gg$ LTO & 2.3637 & 3.0493 & $(0.020)$ \\
LTO $\gg$ LOFDI & 1.7689 & 1.7193 & $(0.700)$ \\
LOFDI $\gg$ LNR & 3.0636 & 4.6144 & $(0.000)$ \\
LNR $\gg$ LOFDI & 1.3189 & 0.7130 & $(0.010)$ \\
LHDI $\gg$ LURB & 5.0966 & 9.1602 & $(0.000)$ \\
LURB $\gg$ LHDI & 3.7207 & 6.0836 & $(0.500)$ \\
LHDI $\gg$ LTO & 3.9021 & 6.4892 & $(0.680)$ \\
LTO $\gg$ LHDI & 2.0137 & 2.2668 & $(0.630)$ \\
LHDI $\gg$ LNR & 3.3154 & 5.1775 & \\
LNR $\gg$ LHDI & 1.4220 & 0.9437 & 3.1616 \\
LTEC $\gg$ LURB & 2.4139 & 1.2899 & \\
LURB $\gg$ LTEC & 1.5769 & & \\
\hline
\end{tabular}


Table 9. Cont.

\begin{tabular}{cccc}
\hline Variable & W-Bar & Z-Bar $(\boldsymbol{p}$-Value $)$ & $\boldsymbol{p}$-Value \\
\hline LURB $\gg$ LTO & 1.0393 & 0.0879 & $(0.940)$ \\
LTO $\gg$ LURB & 3.3783 & 5.3181 & $(0.080)$ \\
LURB $\gg$ LNR & 2.2236 & 2.7360 & $(0.120)$ \\
LNR $\gg$ LURB & 2.1932 & 2.6682 & $(0.150)$ \\
LTO $\gg$ LTEC & 3.1298 & 4.7624 & $(0.020)$ \\
LTEC $\gg$ LTO & 4.4055 & 7.6149 & $(0.000)$ \\
LNR $\gg$ LTEC & 1.8993 & 2.0109 & $(0.400)$ \\
LTEC $\gg$ LNR & 2.4228 & 3.1814 & $(0.250)$ \\
LNR $\gg$ LTO & 2.1011 & 2.4622 & $(0.010)$ \\
LTO $\gg$ LNR & 2.2709 & 2.8417 & $(0.000)$ \\
\hline
\end{tabular}

\section{Conclusions and Policy Recommendations}

This study aimed to compare the environmental and socio-economic performance with OFDI in NIC economies. Using sufficient long panel data series, the study applied an AMG estimator to calculate the association between OFDI, HDI, CFP, and other selected economic variables. The casual association between variables was explored with panel bootstrap Granger causality. We used second-generation unit root tests to empirically investigate the integrated prosperities of the variables, and findings confirmed that $C D$ and heterogeneity were unexpected because of globalization and international agreement. The AMG findings exhibited that in the main effect, increased urbanization, TO, and NR led to a decrease in CFP, while OFDI, HDI, and technology led to an increase in the ED. On the other hand, with moderating effect of OFDI, HDI, technology, and TO led to a decrease in the ED, while NR cause to increase in the level of environmental damages.

Based on the research results, this article presents relevant policy suggestions for the governments of NIC in a straightforward manner.

1. By applying the interaction model, study findings showed a significant increase in technology and environment quality efficiency, which helped shape NIC's image as responsible economies for their human beings. Thus, NIC economies are on the right path to improving environmental quality; policymakers should continue focusing on environmental standards and invest in economies with less environmental regulation. As we found the positive response of OFDI toward the environmental quality, these economies have transferred their outdated industries overseas. As a result, improvement in a domestic environment is happening. This action encourages the clean and green industries in NIC economies through trade liberalization, which will repeat the heaven theory argument that OFDI will transfer polluting industries to other economies with low environmental rules and regulations. Indeed, OFDI is mitigating the adverse effect of heavy pollutant activities and resolving the environmental problems of regional economies by putting low pressure on the environment that is consistent with SDGs. So it can be deduced that OFDI is playing a crucial role in sustainable growth and environment through the diffusion and adaptation of sustainable goods and practices [151];

2. In addition, this study verified afresh the positive effect of human well-being on the environment. Moreover, there is a negative association between social well-being and CFP in moderating effect. Evidence from our result shows the positive impact of the interaction term of FD.HDI on environmental quality can be attributed to the spillover effect of OFDI. This investment is not only associated with environmental quality but also encourages the level of human capital. The selected economies can achieve SDGs by creating employment opportunities for skilled labor by moving in parallel with poverty reduction, educational skills, training, and environmental sustainability. Due to an upsurging trend in economic growth and environmental issues, these economies may not have enough resources to develop their clean energy sources. Therefore, to fulfill the energy demand for economic activities, they rely on 
traditional energy sources, resulting in environmental issues. Human capital with the spillover effect of OFDI can efficiently use traditional energies, which can help in declining the ED. Thus, to attain the SDGs, there is a need to focus on OFDI via the usage of efficient technology through human capital;

3. Most of the NIC's economies make low price imports, which is harming the environment in terms of energy consumption. As TO has a significant impact on the ED, policymakers should revise environmental policies regarding taxes, pollution fees, carbon emissions trading, and environmental information. Results showed that a rise in TO with OFDI (as an interaction term) is reducing emissions. It is important to gradually increase the openness and realize the positive spillover effect of OFDI on emissions reduction. In this way, NIC economies can achieve MDGs and SDGs and grow cleaner businesses with low environmental costs;

4. Furthermore, the NIC economies need to take measures to mitigate the effects of urbanization growth and provide better facilities to improve the living standard. As the NIC region's urbanization is running into a fast-growing period, it is vital to stabilize its rate of urbanization as well as to control carbon emissions. So, to attain a stable urbanization rate and a better environment, NIC nations should launch green housing and green cities projects;

5. The technology spillover effect brought by OFDI can improve the technology level and reduce domestic environmental pollution, while study findings proved that technology with the main effect is not performing well in NIC economies. Contrary, the interaction term of FD.TEC suggests that OFDI is an influential factor for technology; direct investment in this regard harms the environment. Therefore, the spillover effect of OFDI on technology contributes to environmental quality. Therefore, there is a need to encourage OFDI, and concerned governments should invest a significant portion of their OFDI's revenue in sustainable technology-related paths to attain environmental sustainability. Similarly, balanced OFDI in different sectors can complement the OFDI-induced technology spillover by transferring domestic excess capacity [152];

6. Likewise, mineral resource richness has a direct positive influence on environmental quality. Therefore, nations with abundant NR can reduce their import of fossil resources and thus help in controlling environmental quality. In this way, NIC economies can accomplish SDGs and advance environmental quality. Moreover, the NR's interaction term infers that OFDI causes over-exploitation of resources and significantly contributes to environmental pollution. Therefore, governments should closely overlook these activities to protect present and subsequent generations' social and economic welfare.

Based on investigated results, the policy recommendation can be detailed for each nation. In Indonesia, Mexico, and Turkey, OFDI is a more efficient source of environmental pollution. So, in terms of OFDI, all other economies in the selected group should adopt the same pattern to prevent harmful environmental situations. Therefore, it may be rational to increase the OFDI toward other economies to save the local environment. In the Philippines, increasing social well-being (HDI) reduces ED, but some economies observe an increase, and some have an insignificant impact on CFP. We can conclude that HDI causes improved environmental quality in the concerned economy, so the policies that encourage the investment in social well-being will be a plausible choice for other economies.

Moreover, urbanization causes a decrease in environmental pollution in China; therefore, increasing the share of investment in urban areas is highly recommended for a sustainable environment. In addition, all other nations should adopt the green urbanization pattern to prevent the harmful effect of the environment on human well-being. In Turkey, we found that technology use is the most effective source to lessen environmental pollution. In China and Malaysia, increasing TO leads to a cut in ED. In addition, in both concerned economies, environment and trade policies are interlinked in a similar direction. Other nations should adopt suitable policies concerning TO that secure the environmental condition. Finally, empirical findings indicate that increasing NR abundance in Indonesia 
and Mexico leads to decreased CFP emissions. To sum up, it is concluded that OFDI is one of the most efficient determinants to diminish environmental pollution across the NIC economies.

In this study, there are still some limitations, highlighting future research opportunities, and may lead to biasedness: Firstly, the available data for selected variables was up to the year 2017, future studies can use more periods to validate the outcomes of this study. Secondly, this study has followed the empirical strategy of AMG estimator, but alternative panel data techniques based on the non-linear structure may produce different outcomes, which can be used in future studies. Thirdly, this study investigates the determinants of CFP as a measurement of ED, but alternative environmental indicators such as ecological footprint, environmental sustainability index may react to the study variables differently. Fourth, the most important, there is a need to focus on other factors that are closely related to the environment, OFDI, and trade sector, i.e., governance, civil unrest, political stability, internal and external conflicts, and corruption can yield the researchers' interesting outcomes, this study could not include such factors due to data constraints. Improvements in environmental protection appear particularly pronounced in countries where regulations are most distorted due to corruption.

Similarly, efforts to reduce corruption will benefit efficient environmental policymaking. Thus, future researches should use concerned factors, especially corruption, to re-investigate environmental impact. Therefore, new research should use different data with a wide range, estimation techniques, and new control variables to confirm the validity of obtained findings and reveal ED reactions to alternative determinants.

Author Contributions: Q.Z.: Writing-review and editing; S.A.A.N.: reviewing original draft and analysis by software; S.A.R.S.: conceptualization, methodology, and writing original draft. All authors have read and agreed to the published version of the manuscript.

Funding: This research is funded by (National Social Science Foundation of China), grant number (18BJY002), China's mode and evolutionary path of industry transfer in countries along the Belt and Road from the prospective of industrial symbiosis.

Institutional Review Board Statement: Not applicable.

Informed Consent Statement: Not applicable.

Data Availability Statement: The data will be provided by the corresponding author on serious request.

Acknowledgments: The authors are grateful for useful comments offered by three anonymous referees.

Conflicts of Interest: It is submitted that there are no known conflicts of interest associated with this publication that could have influenced its outcome.

$\begin{array}{ll}\text { Abbreviations } \\ \text { HDI } & \text { Human development index (human well-being) } \\ \text { OFDI } & \text { Outward foreign direct investment } \\ \text { TO } & \text { Trade openness } \\ \text { ED } & \text { Environmental degradation } \\ \text { TEC } & \text { Technology } \\ \text { URB } & \text { Urbanization } \\ \text { NR } & \text { Natural resource rents } \\ \text { AMG } & \text { Augmented mean group } \\ \text { CADF } & \text { Covariate-augmented Dickey-Fuller } \\ \text { CIPS } & \text { Cross-sectionally augmented IPS } \\ \text { CD } & \text { Cross-sectional dependence }\end{array}$




\section{Appendix A}

Table A1. Review of the literature.

\begin{tabular}{|c|c|c|c|}
\hline Author & Region & Method & Outcome \\
\hline \multicolumn{4}{|c|}{ Relation of OFDI with Environmental Degradation } \\
\hline Hao et al. [20] & $\begin{array}{l}29 \text { Chinese provinces } \\
\text { (2003-2016) }\end{array}$ & 3SLS & $\begin{array}{c}\text { OFDI } \downarrow \mathrm{CO}_{2} \text { via technical and } \\
\text { composition effect and } \uparrow \text { via } \\
\text { scale effect }\end{array}$ \\
\hline Gong et al. [153] & $\begin{array}{l}30 \text { China provinces } \\
(2004-2015)\end{array}$ & GMM & $\begin{array}{c}\text { Environmental regulation } \uparrow \\
\text { OFDI }\end{array}$ \\
\hline Yu et al. [154] & Belt road initiative countries & PSM-DID & OFDI $\uparrow$ carbon emissions \\
\hline Yang et al. [155] & $\begin{array}{l}30 \text { China provinces } \\
(2003-2017)\end{array}$ & SEM & OFDI $\uparrow$ carbon emissions \\
\hline \multicolumn{4}{|c|}{ Human Well-being and Environmental Degradation } \\
\hline Lawson [156] & $\begin{array}{l}41 \text { Sub-Saharan Africa } \\
\text { (1990-2013) }\end{array}$ & FE model & HDI $\downarrow$ GHGs \\
\hline Akbar et al. [146] & $\begin{array}{l}33 \text { OECD countries } \\
(2006-2016)\end{array}$ & P-VAR & $\begin{array}{c}\mathrm{HDI} \leftrightharpoons \text { emissions and HDI } \downarrow \\
\mathrm{CO}_{2}\end{array}$ \\
\hline Alotaibi and Alajlan [157] & G20 economies & QR & $\mathrm{HDI} \downarrow \mathrm{CO}_{2}$ at 0.2 quantile \\
\hline \multicolumn{4}{|c|}{ Natural Resources and Environmental Degradation } \\
\hline Khan et al. [158] & USA 1971-2016 & GMM and GLM & $\mathrm{NRs} \downarrow \mathrm{CO}_{2}$ \\
\hline Nwani and Adams [30] & 93 economies (1995-2017) & AMG & NRs $\uparrow$ carbon emissions \\
\hline Shittu et al. [159] & $\begin{array}{l}45 \text { economies of Asia } \\
(1990-2018)\end{array}$ & 2SLS & $\begin{array}{c}\text { NRs } \downarrow \text { environmental } \\
\text { degradation }\end{array}$ \\
\hline \multicolumn{4}{|c|}{ Urbanization and Environmental Degradation } \\
\hline Hashmi et al. [160] & $\begin{array}{l}\text { South, South East, and South } \\
\text { Asian economies (1971-2014) }\end{array}$ & $\begin{array}{c}\text { AMG, FMOLS, DOLS, and } \\
\text { DSUR }\end{array}$ & $\begin{array}{l}\text { U-shaped relationship } \\
\text { between urbanization and } \\
\text { environment }\end{array}$ \\
\hline Wang et al. [126] & OECD economies & P-DARDL & $\mathrm{URB} \downarrow \mathrm{CO}_{2}$ \\
\hline Musah et al. [161] & West Africa & DKSER & $\mathrm{URB} \uparrow$ carbon emissions \\
\hline \multicolumn{4}{|c|}{ Trade Openness and Environmental Degradation } \\
\hline Dauda et al. [162] & $\begin{array}{l}9 \text { African countries } \\
(1990-2016)\end{array}$ & FE and GMM & $\begin{array}{c}\mathrm{TO} \uparrow \mathrm{CO}_{2} \text { (under } \mathrm{FE} \text { ), } \mathrm{TO} \downarrow \\
\mathrm{CO}_{2} \text { (under } \mathrm{GMM} \text { ) }\end{array}$ \\
\hline Abokyi et al. [163] & Ghana (1971-2014) & ARDL & $\mathrm{TO} \uparrow \mathrm{CO}_{2}$ \\
\hline Ibrahiem and Hanafy [164] & $\begin{array}{l}\text { North African economies } \\
\qquad(1971-2014)\end{array}$ & PMG-ARDL & $\mathrm{TO} \uparrow \mathrm{CO}_{2}$ \\
\hline \multicolumn{4}{|c|}{ Technology (EI) and Environmental Degradation } \\
\hline Wang et al. [165] & $\begin{array}{l}30 \text { provinces of China } \\
(2004-2016)\end{array}$ & POLS, FE, and GMM & Technology $\uparrow \mathrm{CO}_{2}$ \\
\hline Bekun et al. [166] & $\begin{array}{l}27 \text { European Union economies } \\
\text { (1990-2017) }\end{array}$ & AMG, MG, and CCE-MG & Technology $\uparrow \mathrm{CO}_{2}$ \\
\hline Koyuncu et al. [167] & Turkey (1990-2015) & TAR model & Technology $\uparrow \mathrm{CO}_{2}$ \\
\hline
\end{tabular}

Note: $\mathrm{CO}_{2}$ : carbon emissions, 3SLS: three stages least square, PSM-DID: propensity score matching and difference in difference model, SEM: structural equation model, FE: fixed effect model, P-VAR: panel auto-regression model, QR: quantile regression, GLM: generalized least model, FMOLS: fully modified ordinary least square, DOLS: dynamic ordinary least square, SUR: seemingly un-correlated method, DARDL: dynamic autoregressive distributive lag model, PMG: pooled mean group, $\downarrow$ decrease in, $\uparrow$ increase in, $\leftrightharpoons$ bidirectional relationship.

Table A2. List of selected countries. 
Table A3. Test for multicollinearity.

\begin{tabular}{ccc}
\hline Variable & VIF & 1/VIF \\
\hline L HDI & 3.24 & 0.308374 \\
LOFDI & 3.06 & 0.326937 \\
LTO & 2.31 & 0.433314 \\
LTEC & 1.97 & 0.508789 \\
LURB & 1.47 & 0.681189 \\
LNR & 1.40 & 0.713066 \\
\hline
\end{tabular}

Table A4. Descriptive details of first and last year of panel for selected dependent and independent variables.

\begin{tabular}{|c|c|c|c|c|c|c|c|c|c|c|c|}
\hline Country & & Brazil & China & India & Indonesia & Malaysia & Mexico & Philippines & $\begin{array}{l}\text { South } \\
\text { Africa }\end{array}$ & Thailand & Turkey \\
\hline \multirow{2}{*}{ CFP } & 1990 & $1,606,209.3$ & $3,892,675.2$ & $1,387,371.8$ & $1,165,113.4$ & $198,587.6$ & $494,151.0$ & $96,355.4$ & $188,296.1$ & $208,062.8$ & $1,606,209.3$ \\
\hline & 2017 & $3,207,682.6$ & $14,797,414.2$ & $4,047,189.5$ & $882,536.4$ & $322,775.6$ & $726,806.9$ & $184,796.4$ & $722,885.5$ & $495,007.9$ & $3,207,682.6$ \\
\hline \multirow{2}{*}{ HDI } & 1990 & 0.613 & 0.501 & 0.431 & 0.525 & 0.644 & 0.652 & 0.590 & 0.625 & 0.574 & 0.613 \\
\hline & 2017 & 0.761 & 0.758 & 0.647 & 0.707 & 0.804 & 0.767 & 0.712 & 0.705 & 0.765 & 0.761 \\
\hline \multirow[b]{2}{*}{$\mathrm{TO}$} & 1990 & 0.152 & 0.243 & 0.157 & 0.529 & 1.469 & 0.383 & 0.608 & 0.417 & 0.758 & 0.152 \\
\hline & 2017 & 0.241 & 0.378 & 0.406 & 0.679 & 1.634 & 0.713 & 0.850 & 0.582 & 1.091 & 0.241 \\
\hline \multirow{2}{*}{ NR } & 1990 & 2.285 & 8.189 & 3.412 & 12.261 & 25.862 & 7.977 & 1.928 & 5.778 & 1.100 & 2.285 \\
\hline & 2017 & 4.641 & 1.476 & 2.044 & 4.777 & 6.024 & 3.475 & 1.471 & 5.269 & 1.609 & 4.641 \\
\hline \multirow{2}{*}{ URB } & 1990 & 2.862 & 4.310 & 3.026 & 4.880 & 4.407 & 2.614 & 4.291 & 3.234 & 2.279 & 2.862 \\
\hline & 2017 & 1.094 & 2.694 & 2.379 & 2.329 & 2.199 & 1.628 & 1.979 & 2.021 & 1.793 & 1.094 \\
\hline \multirow{2}{*}{ OFDI } & 1990 & $41,044.1$ & 4455.0 & 124.1 & 86.0 & 753.3 & 2672.4 & 405.0 & $19,413.9$ & 417.6 & $41,044.1$ \\
\hline & 2017 & $239,630.4$ & $1,809,040.0$ & $155,175.7$ & $65,928.4$ & $129,614.2$ & $175,036.4$ & $49,191.1$ & $313,264.4$ & $110,416.4$ & $239,630.4$ \\
\hline
\end{tabular}

Table A4 provides descriptive details of the first and last year of the panel for selected dependent and independent variables for all 10 NIC economies. CFP mean values for all selected economies in the base year were between 96,355 and 3,892,675, and in 2017, these values upsurge and showed a maximum value of 14,797,414 for China. In the case of HDI in the year 1990, its maximum value within the NIC nation was 0.65 for Malaysia, while in 2017, this region has witnessed an increasing trend in human well-being and observed an index value equal to 0.8 . The case of openness in the base year showed a range between 0.15 and 1.46, while in 2017, its range surged to $0.24-1.63$. Nevertheless, for the case of natural resources and urbanization, decreasing trends were observed. Contrary, OFDI showed an increasing pattern from base year to 2017, and an exponential trend has been observed for these nations.

\section{Appendix B}

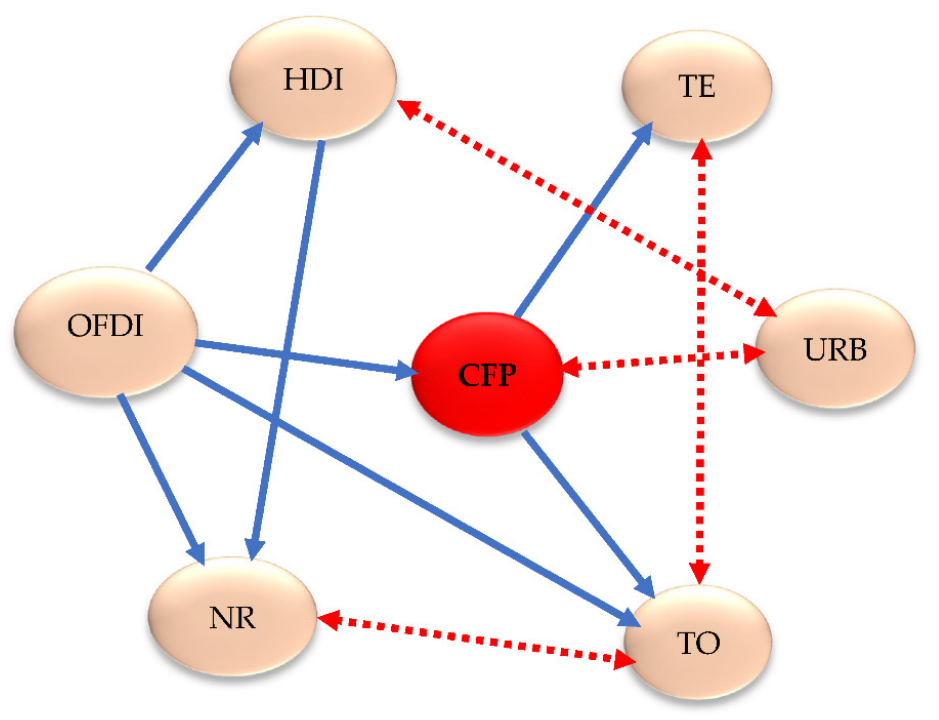

Unidirectional causality and Bi-directional causality

Figure A1. Graphical representation of bootstrap panel causality test. 


\section{References}

1. Grossman, G.M.; Krueger, A.B. Environmental Impacts of a North American Free Trade Agreement (0898-2937). 1991. Available online: https: / /www.nber.org/papers/w3914 (accessed on 15 March 2021).

2. Li, F.; Dong, S.; Li, F.; Yang, L. Is there an inverted U-shaped curve? Empirical analysis of the environmental Kuznets curve in agrochemicals. Front. Environ. Sci. Eng. 2016, 10, 276-287. [CrossRef]

3. Aslan, A.; Destek, M.A.; Okumus, I. Bootstrap rolling window estimation approach to analysis of the Environment Kuznets Curve hypothesis: Evidence from the USA. Environ. Sci. Pollut. Res. 2018, 25, 2402-2408. [CrossRef]

4. Ng, C.-F.; Choong, C.-K.; Ching, S.-L.; Lau, L.-S. The Impact Of Electricity Production From Renewable And Non-Renewable Sources On Co 2 Emissions: Evidence From Oecd Countries. Int. J. Bus. Soc. 2019, 20, 365-382.

5. Katircioglu, S.; Saqib, N.; Katircioglu, S.; Kilinc, C.C.; Gul, H. Estimating the effects of tourism growth on emission pollutants: Empirical evidence from a small island, Cyprus. Air Qual. Atmos. Health 2020, 13, 391-397. [CrossRef]

6. Fethi, S.; Senyucel, E. The role of tourism development on $\mathrm{CO}_{2}$ emission reduction in an extended version of the environmental Kuznets curve: Evidence from top 50 tourist destination countries. Environ. Dev. Sustain. 2020, 23, 1499-1524. [CrossRef]

7. Asongu, S.; El Montasser, G.; Toumi, H. Testing the relationships between energy consumption, $\mathrm{CO}_{2}$ emissions, and economic growth in 24 African countries: A panel ARDL approach. Environ. Sci. Pollut. Res. 2016, 23, 6563-6573. [CrossRef] [PubMed]

8. Zhang, B.; Wang, B.; Wang, Z. Role of renewable energy and non-renewable energy consumption on EKC: Evidence from Pakistan. J. Clean. Prod. 2017, 156, 855-864.

9. Šarauskis, E.; Romaneckas, K.; Kumhála, F.; Kriaučiūnienè, Z. Energy use and carbon emission of conventional and organic sugar beet farming. J. Clean. Prod. 2018, 201, 428-438. [CrossRef]

10. Rahman, M.M.; Kashem, M.A. Carbon emissions, energy consumption and industrial growth in Bangladesh: Empirical evidence from ARDL cointegration and Granger causality analysis. Energy Policy 2017, 110, 600-608. [CrossRef]

11. Bildirici, M.E. The causal link among militarization, economic growth, $\mathrm{CO}_{2}$ emission, and energy consumption. Environ. Sci. Pollut. Res. 2017, 24, 4625-4636. [CrossRef] [PubMed]

12. Appiah, K.; Du, J.; Yeboah, M.; Appiah, R. Causal correlation between energy use and carbon emissions in selected emerging economies-Panel model approach. Environ. Sci. Pollut. Res. 2019, 26, 7896-7912. [CrossRef]

13. Joshua, U.; Uzuner, G.; Bekun, F.V. Revisiting the causal nexus between coal energy consumption, economic growth, and pollutant emission: Sorting out the causality. Environ. Sci. Pollut. Res. 2020, 27, 30265-30274. [CrossRef]

14. He, J. Pollution haven hypothesis and environmental impacts of foreign direct investment: The case of industrial emission of sulfur dioxide $\left(\mathrm{SO}_{2}\right)$ in Chinese provinces. Ecol. Econ. 2006, 60, 228-245. [CrossRef]

15. Agnihotri, A.; Arora, S. Study of Linkages Between Outward Foreign Direct Investment (OFDI) and Domestic Economic Growth: An Indian Perspective. Financ. Mark. Inst. Risks 2019, 3, 43-49. [CrossRef]

16. Chen, C. Impact of China's outward foreign direct investment on its regional economic growth. China World Econ. 2018, 26, 1-21. [CrossRef]

17. Knoerich, J. Has outward foreign direct investment contributed to the development of the Chinese economy? Transnatl. Corp. 2017, 23, 1-48. [CrossRef]

18. Chen, P. Influence of the Level of Financial Development on OFDI in China. Am. J. Ind. Bus. Manag. 2018, 8, 327-340. [CrossRef]

19. Jiang, H.; Hu, Y.-C.; Lin, J.-Y.; Jiang, P. Analyzing China's OFDI using a novel multivariate grey prediction model with Fourier series. Int. J. Intell. Comput. Cybern. 2019, 12, 352-371. [CrossRef]

20. Hao, Y.; Guo, Y.; Guo, Y.; Wu, H.; Ren, S. Does outward foreign direct investment (OFDI) affect the home country's environmental quality? The case of China. Struct. Chang. Econ. Dyn. 2020, 52, 109-119. [CrossRef]

21. Haiyun, L.; Min, L. The Home Country Effect Research of China's OFDI on Carbon Emissions. J. Ind. Technol. Econ. 2016. Available online: https:/ / en.cnki.com.cn/Article_en/CJFDTotal-GHZJ201608002.htm (accessed on 15 March 2021).

22. Long, R.; Zhou, Y. Effect of ofdi reverse technology spillover on regional carbon productivity in China. Ecol. Econ. 2017, 33, 58-62.

23. Gong, M.; Liu, H.; Atif, R.M.; Jiang, X. A study on the factor market distortion and the carbon emission scale effect of two-way FDI. Chin. J. Popul. Resour. Environ. 2019, 17, 145-153. [CrossRef]

24. Jiang, H.; Jiang, P.; Kong, P.; Hu, Y.-C.; Lee, C.-W. A Predictive Analysis of China's CO2 Emissions and OFDI with a Nonlinear Fractional-Order Grey Multivariable Model. Sustainability 2020, 12, 4325. [CrossRef]

25. Xin, D.; Zhang, Y. Threshold Effect of OFDI on China's provincial Environmental Pollution. J. Clean. Prod. 2020, 258, 120608. [CrossRef]

26. Pesaran, M.H. Time Series and Panel Data Econometrics; Oxford University Press: Oxford, UK, 2015.

27. Bond, S.; Eberhardt, M. Accounting for Unobserved Heterogeneity in Panel Time Series Models; University of Oxford: Oxford, UK, 2013.

28. Dong, K.; Sun, R.; Li, H.; Liao, H. Does natural gas consumption mitigate $\mathrm{CO}_{2}$ emissions: Testing the environmental Kuznets curve hypothesis for 14 Asia-Pacific countries. Renew. Sustain. Energy Rev. 2018, 94, 419-429. [CrossRef]

29. Sun, H.; Samuel, C.A.; Amissah, J.C.K.; Taghizadeh-Hesary, F.; Mensah, I.A. Non-linear nexus between $\mathrm{CO}_{2}$ emissions and economic growth: A comparison of OECD and B\&R countries. Energy 2020, 212, 118637.

30. Nwani, C.; Adams, S. Environmental cost of natural resource rents based on production and consumption inventories of carbon emissions: Assessing the role of institutional quality. Resour. Policy 2021, 74, 102282. [CrossRef] 
31. Naqvi, S.A.A.; Shah, S.A.R.; Anwar, S.; Raza, H. Renewable energy, economic development, and ecological footprint nexus: Fresh evidence of renewable energy environment Kuznets curve (RKC) from income groups. Environ. Sci. Pollut. Res. 2021, 28, 2031-2051. [CrossRef]

32. Naqvi, S.A.A.; Shah, S.A.R.; Mehdi, M.A. Revealing empirical association among ecological footprints, renewable energy consumption, real income, and financial development: A global perspective. Environ. Sci. Pollut. Res. 2020, 27, 42830-42849. [CrossRef]

33. Chavers, J.C.; Allen, A.K.; Ahmed, W.; Fuglsang-Damgaard, L.H.; Harrison, A.P. The equine hindlimb proximal suspensory ligament: An assessment of health and function by means of its damping harmonic oscillator properties, measured using an acoustic myography system: A new modality study. J. Equine Vet. Sci. 2018, 71, 21-26. [CrossRef]

34. Mrabet, Z.; Alsamara, M.; Saleh, A.S.; Anwar, S. Urbanization and non-renewable energy demand: A comparison of developed and emerging countries. Energy 2019, 170, 832-839. [CrossRef]

35. Bilgili, F.; Ulucak, R. The nexus between biomass-footprint and sustainable development. Ref. Modul. Mater. Sci. Mater. Eng. 2020, 2, 175-192.

36. Liu, H.Y.; Tang, Y.K.; Chen, X.L.; Poznanska, J. The determinants of Chinese outward FDI in countries along “One Belt One Road". Emerg. Mark. Financ. Trade 2017, 53, 1374-1387. [CrossRef]

37. Kim, D.-H.; Lin, S.-C. Natural resources and economic development: New panel evidence. Environ. Resour. Econ. 2017, 66, 363-391. [CrossRef]

38. Bilgili, F.; Koçak, E.; Bulut, Ü.; Kuloğlu, A. The impact of urbanization on energy intensity: Panel data evidence considering cross-sectional dependence and heterogeneity. Energy 2017, 133, 242-256. [CrossRef]

39. Wang, Q.; Su, M.; Li, R. Toward to economic growth without emission growth: The role of urbanization and industrialization in China and India. J. Clean. Prod. 2018, 205, 499-511. [CrossRef]

40. Ben-Salha, O.; Dachraoui, H.; Sebri, M. Natural resource rents and economic growth in the top resource-abundant countries: A PMG estimation. Resour. Policy 2018, in press. [CrossRef]

41. Mohanty, S.; Sethi, N. Outward FDI, human capital and economic growth in BRICS countries: An empirical insight. Transnatl. Corp. Rev. 2019, 11, 235-249. [CrossRef]

42. Zallé, O. Natural resources and economic growth in Africa: The role of institutional quality and human capital. Resour. Policy 2019, 62, 616-624. [CrossRef]

43. Ramzan, M.; Sheng, B.; Shahbaz, M.; Song, J.; Jiao, Z. Impact of trade openness on GDP growth: Does TFP matter? J. Int. Trade Econ. Dev. 2019, 28, 960-995. [CrossRef]

44. Saleh, H.; Surya, B.; Annisa Ahmad, D.N.; Manda, D. The Role of Natural and Human Resources on Economic Growth and Regional Development: With Discussion of Open Innovation Dynamics. J. Open Innov. Technol. Mark. Complex. $2020,6,103$. [CrossRef]

45. Canh, N.P.; Schinckus, C.; Thanh, S.D. The natural resources rents: Is economic complexity a solution for resource curse? Resour Policy 2020, 69, 101800. [CrossRef]

46. Bingquan, L.; Su, X.; Shi, J.; Hou, R. Does urbanization drive economic growth decoupled from energy consumption in China's logistics? J. Clean. Prod. 2020, 257, 120468.

47. Kong, Q.; Peng, D.; Ni, Y.; Jiang, X.; Wang, Z. Trade openness and Economic Growth Quality of China: Empirical Analysis Using ARDL Model. Financ. Res. Lett. 2020, 38, 101488. [CrossRef]

48. Ding, T.; Ning, Y.; Zhang, Y. The Contribution of China's Outward Foreign Direct Investment (OFDI) to the Reduction of Global $\mathrm{CO}_{2}$ Emissions. Sustainability 2017, 9, 741. [CrossRef]

49. Yi, M.; Gong, M.; Wu, T.; Wang, Y. Nonlinear effects of urbanization and outward foreign direct investment on carbon emissions in China. Sustainability 2018, 10, 4411. [CrossRef]

50. Zhou, Y.; Jiang, J.; Ye, B.; Hou, B. Green spillovers of outward foreign direct investment on home countries: Evidence from China's province-level data. J. Clean. Prod. 2019, 215, 829-844. [CrossRef]

51. Pan, X.; Li, M.; Wang, M.; Chu, J.; Bo, H. The effects of outward foreign direct investment and reverse technology spillover on China's carbon productivity. Energy Policy 2020, 145, 111730. [CrossRef]

52. Elliott, R.J.; Sun, P.; Zhu, T. The direct and indirect effect of urbanization on energy intensity: A province-level study for China. Energy 2017, 123, 677-692. [CrossRef]

53. Behera, S.R.; Dash, D.P. The effect of urbanization, energy consumption, and foreign direct investment on the carbon dioxide emission in the SSEA (South and Southeast Asian) region. Renew. Sustain. Energy Rev. 2017, 70, 96-106. [CrossRef]

54. Ouyang, X.; Lin, B. Carbon dioxide $\left(\mathrm{CO}_{2}\right)$ emissions during urbanization: A comparative study between China and Japan. J. Clean. Prod. 2017, 143, 356-368. [CrossRef]

55. Wang, S.; Li, G.; Fang, C. Urbanization, economic growth, energy consumption, and $\mathrm{CO}_{2}$ emissions: Empirical evidence from countries with different income levels. Renew. Sustain. Energy Rev. 2018, 81, 2144-2159. [CrossRef]

56. Cetin, M.; Ecevit, E.; Yucel, A.G. The impact of economic growth, energy consumption, trade openness, and financial development on carbon emissions: Empirical evidence from Turkey. Environ. Sci. Pollut. Res. 2018, 25, 36589-36603. [CrossRef] [PubMed]

57. Xiao, H.; Cheng, J.; Wang, X. Does the Belt and Road Initiative promote sustainable development? Evidence from countries along the Belt and Road. Sustainability 2018, 10, 4370. [CrossRef] 
58. Shao, Q.; Wang, X.; Zhou, Q.; Balogh, L. Pollution haven hypothesis revisited: A comparison of the BRICS and MINT countries based on VECM approach. J. Clean. Prod. 2019, 227, 724-738. [CrossRef]

59. Zafar, M.W.; Mirza, F.M.; Zaidi, S.A.H.; Hou, F. The nexus of renewable and nonrenewable energy consumption, trade openness, and CO 2 emissions in the framework of EKC: Evidence from emerging economies. Environ. Sci. Pollut. Res. 2019, 26, 15162-15173. [CrossRef]

60. Ali, H.S.; Abdul-Rahim, A.; Ribadu, M.B. Urbanization and carbon dioxide emissions in Singapore: Evidence from the ARDL approach. Environ. Sci. Pollut. Res. 2017, 24, 1967-1974. [CrossRef]

61. Kurniawan, R.; Managi, S. Coal consumption, urbanization, and trade openness linkage in Indonesia. Energy Policy 2018, 121, 576-583. [CrossRef]

62. Osathanunkul, R.; Kingnetr, N.; Sriboonchitta, S. Emissions, Trade Openness, Urbanisation, and Income in Thailand: An Empirical Analysis. In Paper Presented at the International Conference of the Thailand Econometrics Society; Springer: Cham, Switzerland, 2018

63. Gasimli, O.; Naradda Gamage, S.K.; Shihadeh, F.; Rajapakshe, P.S.K.; Shafiq, M. Energy, trade, urbanization and environmental degradation Nexus in Sri Lanka: Bounds testing approach. Energies 2019, 12, 1655. [CrossRef]

64. Nathaniel, S.P. Modelling urbanization, trade flow, economic growth and energy consumption with regards to the environment in Nigeria. GeoJournal 2019, 85, 1499-1513. [CrossRef]

65. Kwakwa, P.A.; Alhassan, H.; Adu, G. Effect of natural resources extraction on energy consumption and carbon dioxide emission in Ghana. Int. J. Energy Sect. Manag. 2020, 45, 175-196. [CrossRef]

66. Saidi, K.; Mbarek, M.B. The impact of income, trade, urbanization, and financial development on $\mathrm{CO}_{2}$ emissions in 19 emerging economies. Environ. Sci. Pollut. Res. 2017, 24, 12748-12757. [CrossRef] [PubMed]

67. Ahmed, K.; Rehman, M.U.; Ozturk, I. What drives carbon dioxide emissions in the long-run? Evidence from selected South Asian Countries. Renew. Sustain. Energy Rev. 2017, 70, 1142-1153. [CrossRef]

68. Zhang, S.; Liu, X.; Bae, J. Does trade openness affect $\mathrm{CO}_{2}$ emissions: Evidence from ten newly industrialized countries? Environ. Sci. Pollut. Res. 2017, 24, 17616-17625. [CrossRef] [PubMed]

69. Bello, M.O.; Solarin, S.A.; Yen, Y.Y. The impact of electricity consumption on $\mathrm{CO}_{2}$ emission, carbon footprint, water footprint and ecological footprint: The role of hydropower in an emerging economy. J. Environ. Manag. 2018, 219, 218-230. [CrossRef]

70. Destek, M.A.; Ulucak, R.; Dogan, E. Analyzing the environmental Kuznets curve for the EU countries: The role of ecological footprint. Environ. Sci. Pollut. Res. 2018, 25, 29387-29396. [CrossRef]

71. Lv, Z.; $\mathrm{Xu}, \mathrm{T}$. Trade openness, urbanization and $\mathrm{CO}_{2}$ emissions: Dynamic panel data analysis of middle-income countries. J. Int Trade Econ. Dev. 2019, 28, 317-330. [CrossRef]

72. Bekun, F.V.; Alola, A.A.; Sarkodie, S.A. Toward a sustainable environment: Nexus between $\mathrm{CO}_{2}$ emissions, resource rent, renewable and nonrenewable energy in 16-EU countries. Sci. Total Environ. 2019, 657, 1023-1029. [CrossRef]

73. Ulucak, R.; Khan, S.U.-D. Determinants of the ecological footprint: Role of renewable energy, natural resources, and urbanization. Sustain. Cities Soc. 2020, 54, 101996.

74. Asongu, S.; Akpan, U.S.; Isihak, S.R. Determinants of foreign direct investment in fast-growing economies: Evidence from the BRICS and MINT countries. Financ. Innov. 2018, 4, 26. [CrossRef]

75. Chen, Y.; Yan, F. International visibility as determinants of foreign direct investment: An empirical study of Chinese provinces. Soc. Sci. Res. 2018, 76, 23-39. [CrossRef] [PubMed]

76. Wang, L.; Li, S. Determinants of foreign direct and indirect investments from the institutional perspective: A comparative analysis between emerging and mature markets. Int. J. Emerg. Mark. 2018, 13, 1330-1347. [CrossRef]

77. Asiamah, M.; Ofori, D.; Afful, J. Analysis of the determinants of foreign direct investment in Ghana. J. Asian Bus. Econ. Stud. 2019, 26, 56-75. [CrossRef]

78. Mahbub, T.; Jongwanich, J. Determinants of foreign direct investment (FDI) in the power sector: A case study of Bangladesh. Energy Strategy Rev. 2019, 24, 178-192. [CrossRef]

79. Canh, N.P.; Binh, N.T.; Thanh, S.D.; Schinckus, C. Determinants of foreign direct investment inflows: The role of economic policy uncertainty. Int. Econ. 2020, 161, 159-172. [CrossRef]

80. Adebayo, E.O.; Gambiyo, S.P. Economic analysis of the determinants of foreign direct investment (FDI) in Nigeria. Arch. Bus. Res. 2020, 8, 74-81. [CrossRef]

81. Appiah-Kubi, S.N.K.; Malec, K.; Kutin, S.B.; Maitah, M.; Chiseni, M.C.; Phiri, J.; Maitah, K. Foreign ownership in Sub-Saharan Africa: Do governance structures matter? Sustainability 2020, 12, 7698. [CrossRef]

82. Azam, M.; Haseeb, M. Determinants of foreign direct investment in BRICS-does renewable and non-renewable energy matter? Energy Strategy Rev. 2021, 35, 100638. [CrossRef]

83. Appiah-Kubi, S.N.K.; Malec, K.; Phiri, J.; Maitah, M.; Gebeltová, Z.; Smutka, L.; Sirohi, J. Impact of Tax Incentives on Foreign Direct Investment: Evidence from Africa. Sustainability 2021, 13, 8661. [CrossRef]

84. Shahzad, U.; Ferraz, D.; Doğan, B.; do Nascimento Rebelatto, D.A. Export product diversification and $\mathrm{CO}_{2}$ emissions: Contextual evidences from developing and developed economies. J. Clean. Prod. 2020, 276, 124146. [CrossRef]

85. Cui, L.; Li, R.; Song, M.; Zhu, L. Can China achieve its 2030 energy development targets by fulfilling carbon intensity reduction commitments? Energy Econ. 2019, 83, 61-73. [CrossRef]

86. Rugani, B.; Vázquez-Rowe, I.; Benedetto, G.; Benetto, E. A comprehensive review of carbon footprint analysis as an extended environmental indicator in the wine sector. J. Clean. Prod. 2013, 54, 61-77. [CrossRef] 
87. Breidenich, C.; Magraw, D.; Rowley, A.; Rubin, J.W. The Kyoto protocol to the United Nations framework convention on climate change. Am. J. Int. Law 1998, 92, 315-331. [CrossRef]

88. Specification, P.A. Specification for the assessment of the life cycle greenhouse gas emissions of goods and services. BSI Br. Stand. ISBN 2008, 978, 580 .

89. Laurent, A.; Olsen, S.I.; Hauschild, M.Z. Limitations of carbon footprint as indicator of environmental sustainability. Environ. Sci. Technol. 2012, 46, 4100-4108. [CrossRef] [PubMed]

90. Kalbar, P.P.; Birkved, M.; Karmakar, S.; Nygaard, S.E.; Hauschild, M. Can carbon footprint serve as proxy of the environmental burden from urban consumption patterns? Ecol. Indic. 2017, 74, 109-118. [CrossRef]

91. Pereira, R.P.T.; Filimonau, V.; Ribeiro, G.M. Score a goal for climate: Assessing the carbon footprint of travel patterns of the English Premier League clubs. J. Clean. Prod. 2019, 227, 167-177. [CrossRef]

92. Ulucak, R.; Ozcan, B. Relationship between energy consumption and environmental sustainability in OECD countries: The role of natural resources rents. Resour. Policy 2020, 69, 101803. [CrossRef]

93. Katircioğlu, S.T.; Taşpinar, N. Testing the moderating role of financial development in an environmental Kuznets curve: Empirical evidence from Turkey. Renew. Sustain. Energy Rev. 2017, 68, 572-586. [CrossRef]

94. Westerlund, J. Testing for error correction in panel data. Oxf. Bull. Econ. Stat. 2007, 69, 709-748. [CrossRef]

95. Baltagi, B.H. The Oxford Handbook of Panel Data; Oxford Handbooks: New York, NY, USA, 2015.

96. Pesaran, M.H. General diagnostic tests for cross section dependence in panels. Empir. Econ. 2004, 60, 13-50. [CrossRef]

97. Friedman, M. The use of ranks to avoid the assumption of normality implicit in the analysis of variance. J. Am. Stat. Assoc. 1937, 32, 675-701. [CrossRef]

98. Frees, E.W. Assessing cross-sectional correlation in panel data. J. Econom. 1995, 69, 393-414. [CrossRef]

99. Levin, A.; Lin, C.-F.; Chu, C.-S. Unit root tests in panel data: Asymptotic and finite-sample properties. J. Econom. 2002, 108, 1-24. [CrossRef]

100. Im, K.S.; Pesaran, M.H. On the Panel Unit Root Tests Using Nonlinear Instrumental Variables (October 2003). Available online: https:/ / ssrn.com/abstract=482463 (accessed on 15 March 2021). [CrossRef]

101. Nathaniel, S.P.; Iheonu, C.O. Carbon dioxide abatement in Africa: The role of renewable and non-renewable energy consumption. Sci. Total Environ. 2019, 679, 337-345. [CrossRef] [PubMed]

102. Eberhardt, M. Estimating panel time-series models with heterogeneous slopes. Stata J. 2012, 12, 61-71. [CrossRef]

103. Phillips, P.C.; Sul, D. Bias in dynamic panel estimation with fixed effects, incidental trends and cross section dependence. J. Econom. 2007, 137, 162-188. [CrossRef]

104. Destek, M.A.; Sarkodie, S.A. Investigation of environmental Kuznets curve for ecological footprint: The role of energy and financial development. Sci. Total Environ. 2019, 650, 2483-2489. [CrossRef]

105. Kar, M.; Nazlığlu, S..; Ağır, H. Financial development and economic growth nexus in the MENA countries: Bootstrap panel granger causality analysis. Econ. Model. 2011, 28, 685-693. [CrossRef]

106. Cai, L.; Firdousi, S.F.; Li, C.; Luo, Y. Inward foreign direct investment, outward foreign direct investment, and carbon dioxide emission intensity-threshold regression analysis based on interprovincial panel data. Environ. Sci. Pollut. Res. 2021, 28, 46147-46160. [CrossRef] [PubMed]

107. Sarkodie, S.A. The invisible hand and EKC hypothesis: What are the drivers of environmental degradation and pollution in Africa? Environ. Sci. Pollut. Res. 2018, 25, 21993-22022. [CrossRef]

108. Sarkodie, S.A.; Strezov, V. Assessment of contribution of Australia's energy production to $\mathrm{CO}_{2}$ emissions and environmental degradation using statistical dynamic approach. Sci. Total Environ. 2018, 639, 888-899. [CrossRef] [PubMed]

109. Fan, Y.; Liu, L.-C.; Wu, G.; Wei, Y.-M. Analyzing impact factors of $\mathrm{CO}_{2}$ emissions using the STIRPAT model. Environ. Impact Assess. Rev. 2006, 26, 377-395. [CrossRef]

110. Pachauri, S.; Jiang, L. The household energy transition in India and China. Energy Policy 2008, 36, 4022-4035. [CrossRef]

111. Dodman, D. Blaming cities for climate change? An analysis of urban greenhouse gas emissions inventories. Environ. Urban. 2009, 21, 185-201. [CrossRef]

112. Lin, B.; Liu, X. China's carbon dioxide emissions under the urbanization process: Influence factors and abatement policies. Econ. Res. J. 2010, 8, 66-78.

113. York, R. Demographic trends and energy consumption in European Union Nations, 1960-2025. Soc. Sci. Res. 2007, 36, 855-872. [CrossRef]

114. Cole, M.A.; Neumayer, E. Examining the impact of demographic factors on air pollution. Popul. Environ. 2004, 26, 5-21. [CrossRef]

115. DeFries, R.; Pandey, D. Urbanization, the energy ladder and forest transitions in India's emerging economy. Land Use Policy 2010, 27, 130-138. [CrossRef]

116. Zhang, Y.; Zhang, S. The impacts of GDP, trade structure, exchange rate and FDI inflows on China's carbon emissions. Energy Policy 2018, 120, 347-353. [CrossRef]

117. Shahbaz, M.; Sharma, R.; Sinha, A.; Jiao, Z. Analyzing nonlinear impact of economic growth drivers on $\mathrm{CO}_{2}$ emissions: Designing an SDG framework for India. Energy Policy 2021, 148, 111965. [CrossRef]

118. Balsalobre-Lorente, D.; Shahbaz, M.; Roubaud, D.; Farhani, S. How economic growth, renewable electricity and natural resources contribute to $\mathrm{CO}_{2}$ emissions? Energy Policy 2018, 113, 356-367. [CrossRef] 
119. Liu, L.; Zhao, Z.; Zhang, M.; Zhou, C.; Zhou, D. The effects of environmental regulation on outward foreign direct investment's reverse green technology spillover: Crowding out or facilitation? J. Clean. Prod. 2020, 284, 124689. [CrossRef]

120. Kassouri, Y.; Altıntaş, H. Human well-being versus ecological footprint in MENA countries: A trade-off? J. Environ. Manag. 2020, 263, 110405. [CrossRef]

121. Aye, G.C.; Edoja, P.E. Effect of economic growth on $\mathrm{CO}_{2}$ emission in developing countries: Evidence from a dynamic panel threshold model. Cogent Econ. Financ. 2017, 5, 1379239. [CrossRef]

122. Costa, L.; Rybski, D.; Kropp, J.P. A human development framework for $\mathrm{CO}_{2}$ reductions. PLoS ONE 2011, 6, e29262. [CrossRef] [PubMed]

123. Fan, J.-S.; Zhou, L. Impact of urbanization and real estate investment on carbon emissions: Evidence from China's provincial regions. J. Clean. Prod. 2019, 209, 309-323. [CrossRef]

124. Lin, S.; Wang, S.; Marinova, D.; Zhao, D.; Hong, J. Impacts of urbanization and real economic development on $\mathrm{CO}_{2}$ emissions in non-high income countries: Empirical research based on the extended STIRPAT model. J. Clean. Prod. 2017, 166, 952-966. [CrossRef]

125. Liu, X.; Bae, J. Urbanization and industrialization impact of $\mathrm{CO}_{2}$ emissions in China. J. Clean. Prod. 2018, 172, 178-186. [CrossRef]

126. Wang, W.-Z.; Liu, L.-C.; Liao, H.; Wei, Y.-M. Impacts of urbanization on carbon emissions: An empirical analysis from OECD countries. Energy Policy 2021, 151, 112171. [CrossRef]

127. Pata, U.K. The effect of urbanization and industrialization on carbon emissions in Turkey: Evidence from ARDL bounds testing procedure. Environ. Sci. Pollut. Res. 2018, 25, 7740-7747. [CrossRef]

128. Sadorsky, P. The effect of urbanization on $\mathrm{CO}_{2}$ emissions in emerging economies. Energy Econ. 2014, 41, 147-153. [CrossRef]

129. Adams, S.; Acheampong, A.O. Reducing carbon emissions: The role of renewable energy and democracy. J. Clean. Prod. 2019, 240, 118245. [CrossRef]

130. Ulucak, R.; Khan, S.U.D. Relationship between energy intensity and $\mathrm{CO}_{2}$ emissions: Does economic policy matter? Sustain. Dev. 2020, 28, 1457-1464.

131. Wang, S.; Zeng, J.; Liu, X. Examining the multiple impacts of technological progress on $\mathrm{CO}_{2}$ emissions in China: A panel quantile regression approach. Renew. Sustain. Energy Rev. 2019, 103, 140-150. [CrossRef]

132. Shah, S.A.R.; Naqvi, S.A.A.; Anwar, S. Exploring the linkage among energy intensity, carbon emission and urbanization in Pakistan: Fresh evidence from ecological modernization and environment transition theories. Environ. Sci. Pollut. Res. 2020, 27, 40907-40929. [CrossRef] [PubMed]

133. Wang, Q.; Zhang, F. The effects of trade openness on decoupling carbon emissions from economic growth-evidence from 182 countries. J. Clean. Prod. 2021, 279, 123838. [CrossRef] [PubMed]

134. Nepal, R.; Paija, N.; Tyagi, B.; Harvie, C. Energy security, economic growth and environmental sustainability in India: Does FDI and trade openness play a role? J. Environ. Manag. 2021, 281, 111886. [CrossRef] [PubMed]

135. Gozgor, G. Does trade matter for carbon emissions in OECD countries? Evidence from a new trade openness measure. Environ. Sci. Pollut. Res. 2017, 24, 27813-27821. [CrossRef] [PubMed]

136. Shahbaz, M.; Gozgor, G.; Adom, P.K.; Hammoudeh, S. The technical decomposition of carbon emissions and the concerns about FDI and trade openness effects in the United States. Int. Econ. 2019, 159, 56-73. [CrossRef]

137. Reyes, A.B.; Newburry, W.; Carneiro, J.; Cordova, C. Using Latin America as a research laboratory: The moderating effect of trade openness on the relationship between inward and outward FDI. Multinatl. Bus. Rev. 2019, 27, 122-140. [CrossRef]

138. Sun, H.; Attuquaye Clottey, S.; Geng, Y.; Fang, K.; Clifford Kofi Amissah, J. Trade openness and carbon emissions: Evidence from belt and road countries. Sustainability 2019, 11, 2682. [CrossRef]

139. Taghizadeh-Hesary, F.; Rasoulinezhad, E. Analyzing Energy Transition Patterns in Asia: Evidence From Countries with Different Income Levels. Front. Energy Res. 2020, 8, 162. [CrossRef]

140. Taghizadeh-Hesary, F.; Rasoulinezhad, E.; Yoshino, N.; Chang, Y.; Taghizadeh-Hesary, F.; Morgan, P.J. The energy-pollutionhealth nexus: A panel data analysis of low-and middle-income Asian countries. Singap. Econ. Rev. 2021, 66, 435-455. [CrossRef]

141. Zaman, K.; Shahbaz, M.; Loganathan, N.; Raza, S.A. Tourism development, energy consumption and Environmental Kuznets Curve: Trivariate analysis in the panel of developed and developing countries. Tour. Manag. 2016, 54, 275-283. [CrossRef]

142. Al-Mulali, U.; Fereidouni, H.G.; Lee, J.Y.; Sab, C.N.B.C. Exploring the relationship between urbanization, energy consumption, and CO2 emission in MENA countries. Renew. Sustain. Energy Rev. 2013, 23, 107-112. [CrossRef]

143. Bekhet, H.A.; Othman, N.S. Impact of urbanization growth on Malaysia $\mathrm{CO}_{2}$ emissions: Evidence from the dynamic relationship. J. Clean. Prod. 2017, 154, 374-388. [CrossRef]

144. Wang, Q.; Zeng, Y.-E.; Wu, B.-W. Exploring the relationship between urbanization, energy consumption, and $\mathrm{CO}_{2}$ emissions in different provinces of China. Renew. Sustain. Energy Rev. 2016, 54, 1563-1579. [CrossRef]

145. Wang, Z.; Zhang, B.; Wang, B. Renewable energy consumption, economic growth and human development index in Pakistan: Evidence form simultaneous equation model. J. Clean. Prod. 2018, 184, 1081-1090. [CrossRef]

146. Akbar, M.; Hussain, A.; Akbar, A.; Ullah, I. The dynamic association between healthcare spending, $\mathrm{CO}_{2}$ emissions, and human development index in OECD countries: Evidence from panel VAR model. Environ. Dev. Sustain. 2021, 23, 10470-10489. [CrossRef]

147. Mohamed, E.I.H.A.; Adel, B.Y.; Cuong, N.V.; Agnès, S. Effects of Urbanization on Economic Growth and Human Capital Formation in Africa 2014, 〈halshs-01068271〉. Available online: https://halshs.archives-ouvertes.fr/halshs-01068271 (accessed on 15 March 2021). 
148. Adom, P.K. Asymmetric impacts of the determinants of energy intensity in Nigeria. Energy Econ. 2015, 49, 570-580. [CrossRef]

149. Rafiq, S.; Salim, R.; Nielsen, I. Urbanization, openness, emissions, and energy intensity: A study of increasingly urbanized emerging economies. Energy Econ. 2016, 56, 20-28. [CrossRef]

150. Ahmed, K. Revisiting the role of financial development for energy-growth-trade nexus in BRICS economies. Energy 2017, 128, 487-495. [CrossRef]

151. Tiba, S.; Belaid, F. The pollution concern in the era of globalization: Do the contribution of foreign direct investment and trade openness matter? Energy Econ. 2020, 92, 104966. [CrossRef]

152. Razzaq, A.; An, H.; Delpachitra, S. Does technology gap increase FDI spillovers on productivity growth? Evidence from Chinese outward FDI in Belt and Road host countries. Technol. Forecast. Soc. Chang. 2021, 172, 121050. [CrossRef]

153. Gong, M.; Yi, M.; Liu, H.; Jiang, X. Environmental regulation, the hidden economy, and China's outward foreign direct investment. Chin. J. Popul. Resour. Environ. 2020, 18, 35-41. [CrossRef]

154. Yu, P.; Cai, Z.; Sun, Y. Does the emissions trading system in developing countries accelerate carbon leakage through OFDI? Evidence from China. Energy Econ. 2021, 101, 105397. [CrossRef]

155. Yang, T.; Dong, Q.; Du, Q.; Du, M.; Dong, R.; Chen, M. Carbon dioxide emissions and Chinese OFDI: From the perspective of carbon neutrality targets and environmental management of home country. J. Environ. Manag. 2021, 295, 113120. [CrossRef]

156. Lawson, L.A. GHG emissions and fossil energy use as consequences of efforts of improving human well-being in Africa. J. Environ. Manag. 2020, 273, 111136. [CrossRef] [PubMed]

157. Alotaibi, A.A.; Alajlan, N. Using Quantile Regression to Analyze the Relationship between Socioeconomic Indicators and Carbon Dioxide Emissions in G20 Countries. Sustainability 2021, 13, 7011. [CrossRef]

158. Khan, I.; Hou, F.; Le, H.P. The impact of natural resources, energy consumption, and population growth on environmental quality: Fresh evidence from the United States of America. Sci. Total Environ. 2021, 754, 142222. [CrossRef] [PubMed]

159. Shittu, W.; Adedoyin, F.F.; Shah, M.I.; Musibau, H.O. An investigation of the nexus between natural resources, environmental performance, energy security and environmental degradation: Evidence from Asia. Resour. Policy 2021, 73, 102227. [CrossRef]

160. Hashmi, S.H.; Fan, H.; Habib, Y.; Riaz, A. Non-linear relationship between urbanization paths and $\mathrm{CO}_{2}$ emissions: A case of South, South-East and East Asian economies. Urban Clim. 2021, 37, 100814. [CrossRef]

161. Musah, M.; Kong, Y.; Mensah, I.A.; Antwi, S.K.; Donkor, M. The connection between urbanization and carbon emissions: A panel evidence from West Africa. Environ. Dev. Sustain. 2021, 23, 11525-11552. [CrossRef]

162. Dauda, L.; Long, X.; Mensah, C.N.; Salman, M.; Boamah, K.B.; Ampon-Wireko, S.; Dogbe, C.S.K. Innovation, trade openness and $\mathrm{CO}_{2}$ emissions in selected countries in Africa. J. Clean. Prod. 2021, 281, 125143. [CrossRef]

163. Abokyi, E.; Appiah-Konadu, P.; Tangato, K.F.; Abokyi, F. Electricity consumption and carbon dioxide emissions: The role of trade openness and manufacturing sub-sector output in Ghana. Energy Clim. Chang. 2021, 2, 100026. [CrossRef]

164. Ibrahiem, D.M.; Hanafy, S.A. Do energy security and environmental quality contribute to renewable energy? The role of trade openness and energy use in North African countries. Renew. Energy 2021, 179, 667-678. [CrossRef]

165. Wang, Y.; Liao, M.; Xu, L.; Malik, A. The impact of foreign direct investment on China's carbon emissions through energy intensity and emissions trading system. Energy Econ. 2021, 97, 105212. [CrossRef]

166. Bekun, F.V.; Alola, A.A.; Gyamfi, B.A.; Yaw, S.S. The relevance of EKC hypothesis in energy intensity real-output trade-off for sustainable environment in EU-27. Environ. Sci. Pollut. Res. 2021, 28, 51137-51148. [CrossRef] [PubMed]

167. Koyuncu, T.; Beşer, M.K.; Alola, A.A. Environmental sustainability statement of economic regimes with energy intensity and urbanization in Turkey: A threshold regression approach. Environ. Sci. Pollut. Res. 2021, 28, 42533-42546. [CrossRef] 